Historic, Archive Document

Do not assume content reflects current

scientific knowledge, policies, or practices. 
. 


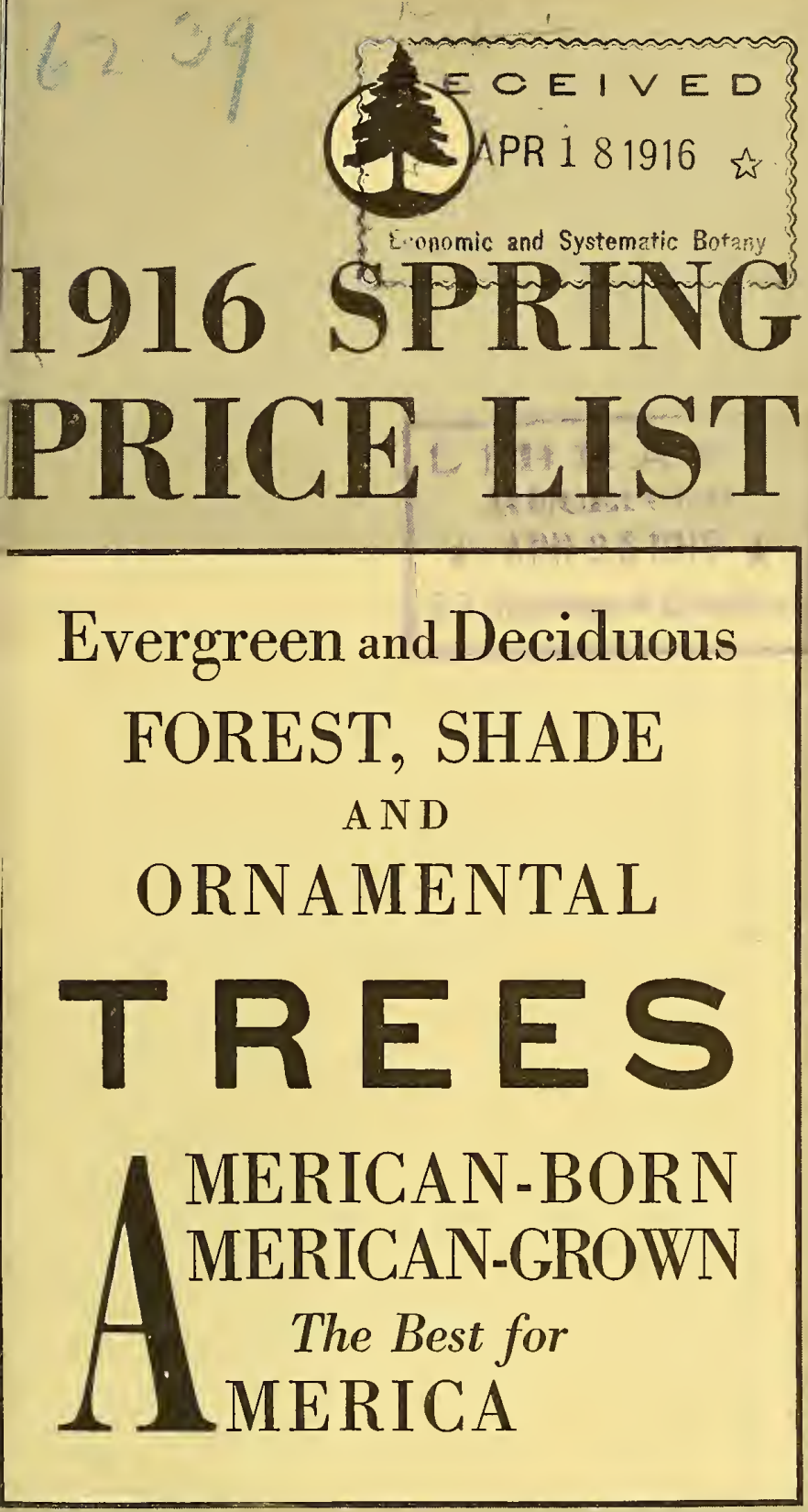

ZI ittle Tree Jarmo of America 50

BIRTHPLACE OF THE LITTLE TREES THAT LIVE

Nurseries of

American Forestry Company 15 Beacon Street - Boston, Massachusetts 


.




\section{ENGINEERING DEPAR'TMEN'T}

\section{ADVICE \\ PLANS \\ SUPER VISION}

\section{Forest Landscaping and Arboriculture}

Development of country estates, pleasure woods, forest parks and game preserves, state and town reservations. We make the most accurately finished plans or a merely suggestive field sketch, as needed.

Laying out vistas, roads, paths and trails; planting schemes and lists of material for shade and ornamental planting, avenues, screens, hedges, windbreaks, etc.

Examinations and advice regarding unthrifty, diseased or injured trees. We co-operate with landscape architects and state or city park commissions.

\section{Commercial Forestry}

Timber valuations and estimates for purchase or sale, and for operation. Working plans (and supervision) for management of timber tracts, woodlands and hunting preserves. Forest and topographical surveys; logging maps. Reforestation plans for wood crops, watershed protection, timber, pulp, railroad and mining supplies, etc.

\section{SERVICE DEPARTMENT}

\section{WOODS WORK}

\section{TREE WORK}

\section{GENERAL WORK}

The service department is skilled in all the work connected with forest landscaping, except, of course, design or professional advice. The men are experienced in thinnings and all cuttings for development, in road and trail making, building simple bridges and rustic shelters, tree plantings of every description, and in making private nurseries and little tree gardens.

Our workmen are skillful, reliable and industrious; long in our employ. The foremen are men of intelligence and character, who have been trained in our methods for a period of years. And the organization is directed by men of the highest technical training in this country, supplemented by foreign study and five to fifteen years of active and varied practical experience.

\section{NURSERIES DEPARTMENT}

\section{TREES AND SHRUBS}

SEEDS

\section{GENERAL SUPPLIES}

Little Trees and Shrubs for commercial and pleasure forest planting; for shade, ornamental, street and "underwood" planting; nut trees; trees for screens, windbreaks and hedges; food plants for game and birds. Everything for Ornamental Planting, in choice quality. Evergreen and deciduous trees, shrubs and vines. Let us have a list of your needs.

Large Specimen Trees, as desired, and at reasonable cost. Consult us first.

Forest Tree Seeds of evergreen and deciduous trees, of American and foreign origin, collected, cleaned, and forwarded promptly from this country and abroad. We supply absolutely the best seed obtainable of the season's crop.

General Supplies, special instruments, tools and equipment, spraying materials, tree paints and wood preservatives. The best quality and design assured. In writing, give your exact requirements. 


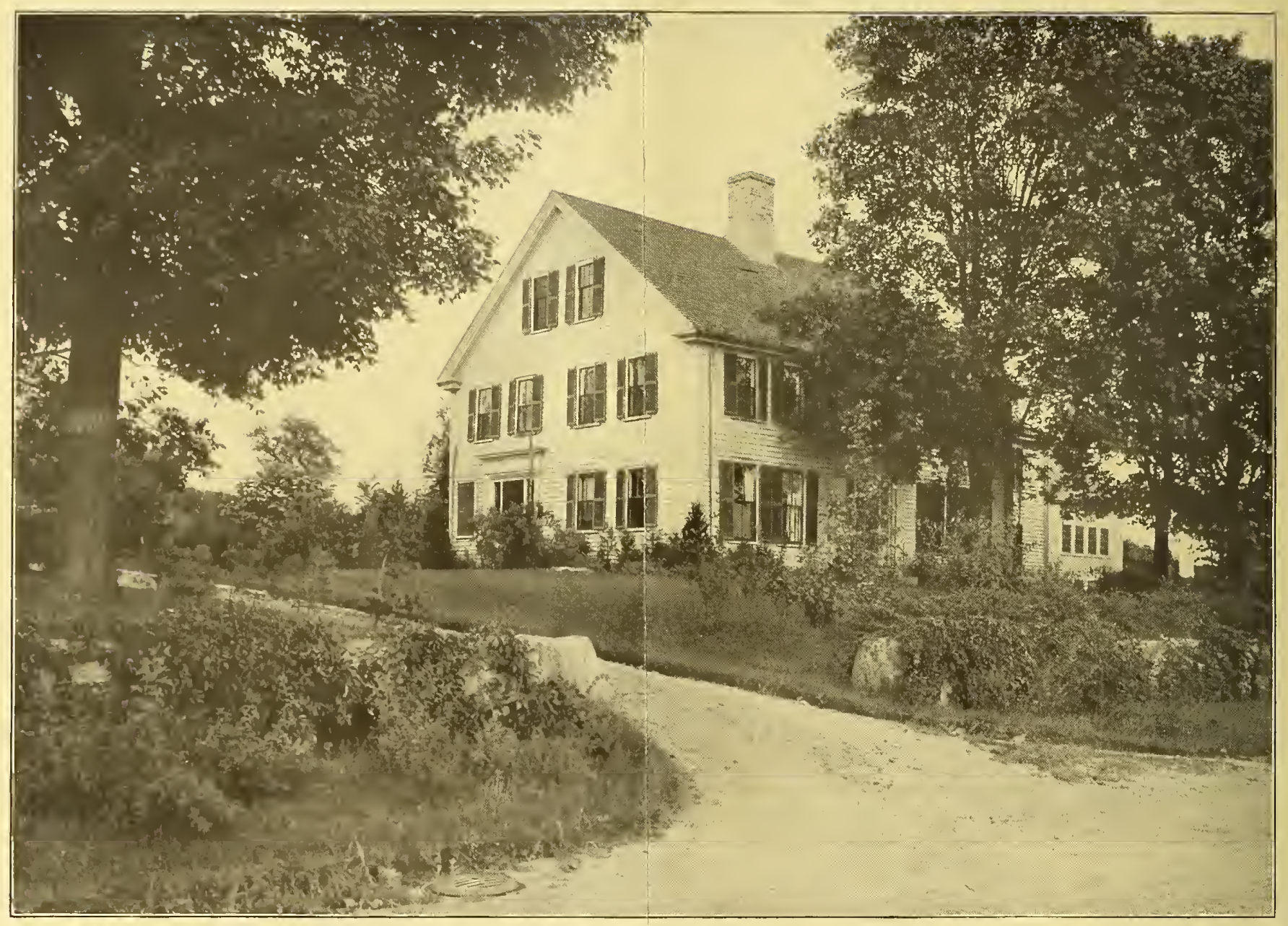

OFFICE OF Tittle TrR Ifarmi, HARTFORD STREET, FRAMINGHAM, MASS.

The above is a view of the local office of the Ifittl Erre Farmi uf Antrina on Hartford Street, Framingham, Mass. Ten years ago this was the only office of the American Forestry Company. In order to efficiently handle the ever increasing business of the company it became necessary to establish offices elsewhere. Three and one-half years ago we moved our general offices to 15 Beacon Street, Boston, and now we also have a branch office in New York City, Room 5733, Grand Central Terminal Building.

Write us regarding your tree or forestry problems and let us help solve them. That is our business. We can help you and it is a pleasure to do so.

All communications should be addressed to our Boston offices where we have a competent office staff to handle orders, inquiries, etc.

We grow trees and shrubs other than those listed in this booklet. Write for special quotations to cover your wants. 


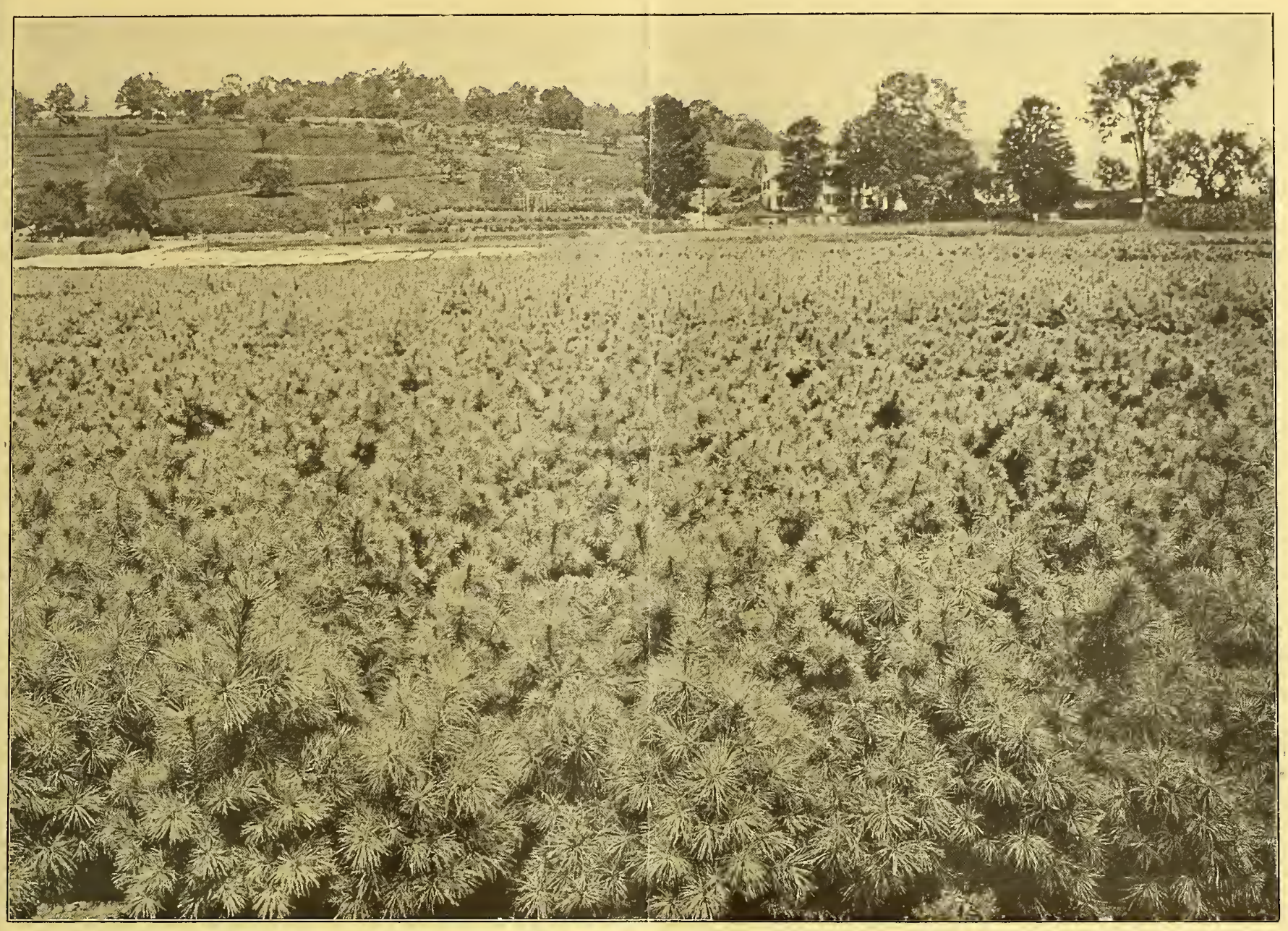

A few acres of our nurseries, Iittle Tre Farma, showing in the foreground a field of many thousands of transplanted White Pines, eighteen to twenty-four inches high.

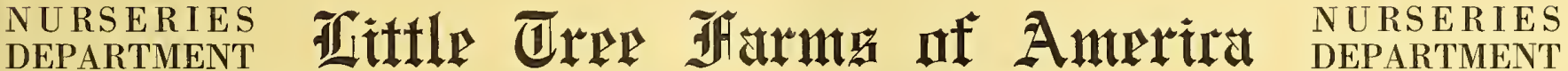 \\ THE GREAT FARMS OF LITTLE TREES OF LARGE VALUES AND SMALL PRICES \\ HARTFORD STREET， FRAMINGHAM， MASSACHUSETTS}

Inittle đrep Ifarms of Amerira. nurseries of the American Forestry Company, are only ten years old, but during that short period they have become the largest forest nurseries in America. An annual crop of many million trees is raised on these farms, all grown from seed collected either by our own men or other men we can trust. We do not use chcmical fertilizers, nor shade and protection, which give a deceptive appearance of height and color, but make for tenderness and succulence rather than hardiness, "woodiness" and endurance. Our trees are kept absolutely free from weeds, insect pests and diseases. We import nothing, therefore our plants are never exposed to the contagion of imported diseases.

We do not "store" any stock. The plants at Trittle Ire 3farma are kept growing right up to the shipping time and are dug fresh, packed fresh and shipped fresh to you when you want them. 


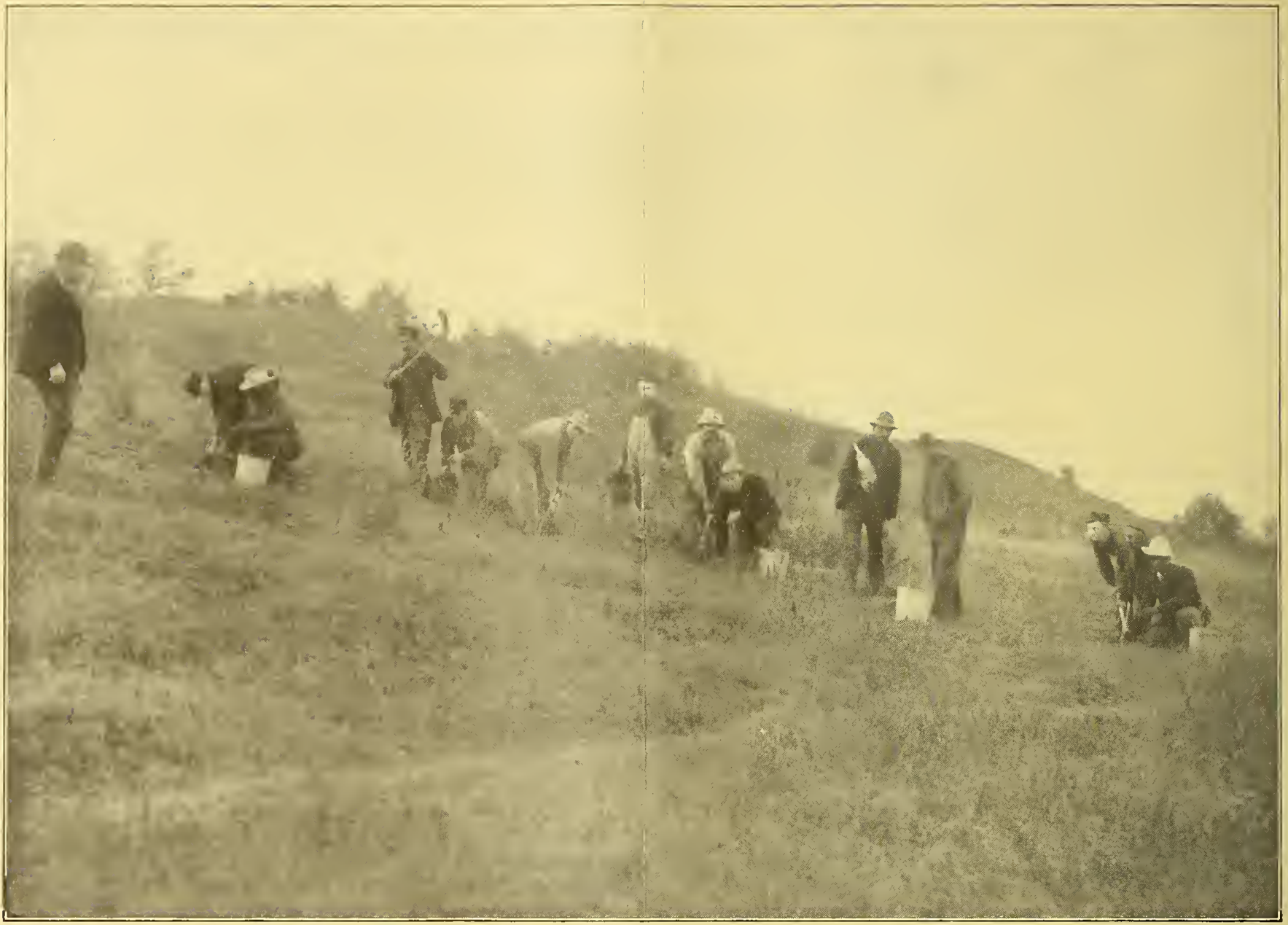

The above illustration shows how our men work in pairs when making commercial plantations; one of the men digs the holes and the other places and sets the trees.

\section{PLANTING SERVICE}

Through our Service Department we offer you skilled foremen and men to plant your trees. This department has planted more than four million trees for customers in the past six years. The men have had ten yeare' experience under our superintendent. They are skilled in handling all sizes and kinds of trees, and in making plantings for all purposes. We carry twelve crews through the season and a sufficient number of these skilled men is put on every planting, with some local labor as helpers, to reduce the cost to the customer. The long experience these men have had in this line of work reduces the loss of plants to the lowest possible per cent and the skill of the men makes the work very economical.

We have made the following kinds of plantings for customers:

1. Commercial plantings for commercial concerns for different purposes.

2. Commercial plantings for estate owners.

3. Protective or public service plantings, water sheds and reservations, parks, etc.

4. Landscape plantings, including decorative and general planting on private grounds. j. Underplanting.

6. Auxiliary plantings.

7. Screen and protective plantings.

8. Group plantings.

9. Little Tree Gardens.

10. Street and avenue plantings. 
The GREAT Farms of LITTLE Trees of LARGE Values and SMALL Prices

\section{INFORMATION}

RAILROADS. Boston \& Albany, main line, New York Central

New York, New Haven \& Hartford.

Boston \& Maine (via short branch).

EXPRESSES. Adams, American, and Connecting Agencies,

U. S. MAILS. Parcel Post.

TELEGRAPH. Western Union Telegrapb \& Cable Company.

CODES.

Western Union; Nurserymen's Telegraphic. A B C (fifth edition).

Our Cable Address: "Amforestco," Boston.

SHIPPING SEASONS.

In Spring - From middle of March to about June 1. The planting season is determined NOT by the state of vegetation where the planting is to be done BUT by the condition of the trees to be planted. So long as they are dormant they may safely be transplanted. It they are dormant they may safely be transplanted. is safe to ship plants to Southern localities later than setts is dormant later than farther soutb.

In Fall - August and September for Evergreens. About October 1st for Hard woods. Shipping continues until the ground freezes.

PLEASE ORDER EARLY - so that we can satisfy you with good, prompt service (not rush work). The shipping season is limited. Orders must be filled in succession as received; justice requires this.

\section{PLEASE GIVE SHIPPING INSTRUGTIONS}

Kindly state:

1. Address for marking the sbipment.

2. Address for mail.

3. Shall we forward by freight? express? parcel post?

4. Approximate time when shipment shall be made.

In the absence of instructions, we shall use our best judgment.

Our responsibility, of course, ceases upon delivery to the trans-

portation company. We do not pay transportation charges.

Shipments travel at customer's risk.

DELIVERIES. Free by auto truck to freights, expresses, and mails, thus insuring the greatest promptness.

\section{TRANSPORTATION.}

We advise tbe use of quick transportation modes.

Tbe low special express rate on trees, plants, and seeds is 25 per cent less than on regular merchandise; express companies occasionally overlook this.

The new Parcel Post regulations permit much more extensive use of tbe mails tban has been possible up to this time.

\section{TO GUSTOMERS}

WARRANTY AND REPLACEMENT. We use the greatest care in following instruetions, and our intention is invariably to send out only first-class plants and seeds, true to label, well packed, and in good condition, addressed as directed and delivered to such transporting company as directed. Here our responsibility ceases.

We gladly rectify errors or claims if made upon receipt of goods, but cannot be liable for more than the purchase price. The prices cannot be liable for more than the purchase price. The prices
are not made to cover a possible second shipment. They are the lowest statement of value of one shipment of first-class trees. It is humanly impossible to guarantee the growth of plants, since so many causes, known and unknown, can injure or kill them. If exposure or drought, poor planting, bad weather, accident, or otber causes kill plants bought of us, we cannot in fairness be help responsible. Claim for delay en route should be taken up with tbe transporting company. We cannot replace the plants without cost.

We GUARANTEe To SUPPLy Fine PLANTS,

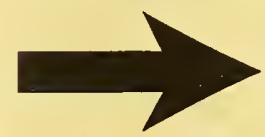

DUG

PACKED

SHIPPED

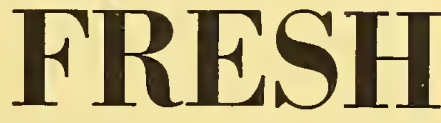

WE SHIP trees: Dug upon order (not cellared or "heeled in" stock). Handled with the care due to young trees.

Bundled in convenient sizes of 25,50 , or 100 plants, and usually a few more for good measure. The bundles are carefully tied, and the gradings are according to our Price Lists. To avoid confusion, we ask our customers kindly to follow these gradwe ask our custon

Packed at once in the moist air of a thoroughly modern packing cellar, and packed right, according to species, time of year, and distance.

Delivered promptly to the transportation company.

WE IMPORT NOTHING, thereby avoiding unacclimatized, devitalized, dried, or moldy stock, and the insect and fungoid infection usually attacbing to imported stock.

INSPECTION CERTIFICATES of the United States Department of Agriculture and the State of Massachusetts Entomological Department accompany each shipment and assure healthy, clean partment

RATES: We sell 500 or more trees of the same size and species at the thousand rate; between 50 and 500 at the hundred rate; less than 50 at the ten rate.

WRITE FOR SPECIAL QUOTATIONS in large quantities.

TERMS OF PAYMENT.

Cash witb order, except by special arrangement.

Please send eheck or draft on New York or Boston banks, post office or express money order, or cash in registered mail.

C. O. D. deliveries, please enclose 50 per cent of amount of bill with order.

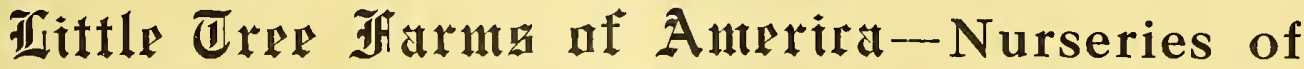 AMERICAN FORESTRY COMPANY 15 BEAGON STREET, BOSTON, MASS.}

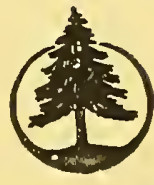

A GHARGE FOR PACKING MATERIAL IS MADE AT ACTUAL COST 


\section{G ON IFEROUS TREES (Evergreens)}

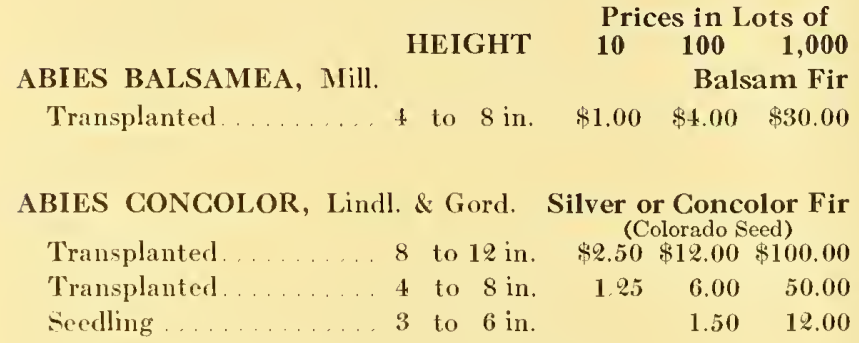

JUNIPERUS CHINENSIS PROGUMBENS.

Twice Transplanterd ... 12, to: $18 \mathrm{in} . \quad \$ 8,00$

\begin{abstract}
Prices in Lots of
HEIGHT $10 \quad 100 \quad 1,000$

JUNIPERUS VIRGINIANA, Linn. Juniper: Savin: Red Cedar
\end{abstract}

Twice Transplanted ... $3 \frac{1}{2}$ to $4 \mathrm{ft}$. $\$ 15.00 \$ 85.00 \quad \$ 650.00$

$\begin{array}{llllll}\text { Twice Transplanted .... } & 2 \frac{1}{2} \text { to } & 3 \mathrm{ft} . & 12.00 & 60.00 & 500.00\end{array}$

Twice Transplanted ... $\quad 1 \frac{1}{2}$ to $2 \mathrm{ft} . \quad 8.00 \quad 40.00 \quad 300.00$

For color, symmetry, and architectural suggestiveness of line, no ornamental tree is superior to the Juniper. All of our Junipers are grown from seed gathered by our own men from mature, vigorous trees in the neighborhood of our nursery. They are especially hardy, and in great demand. (See illustration of individual Juniper on Page 15.)

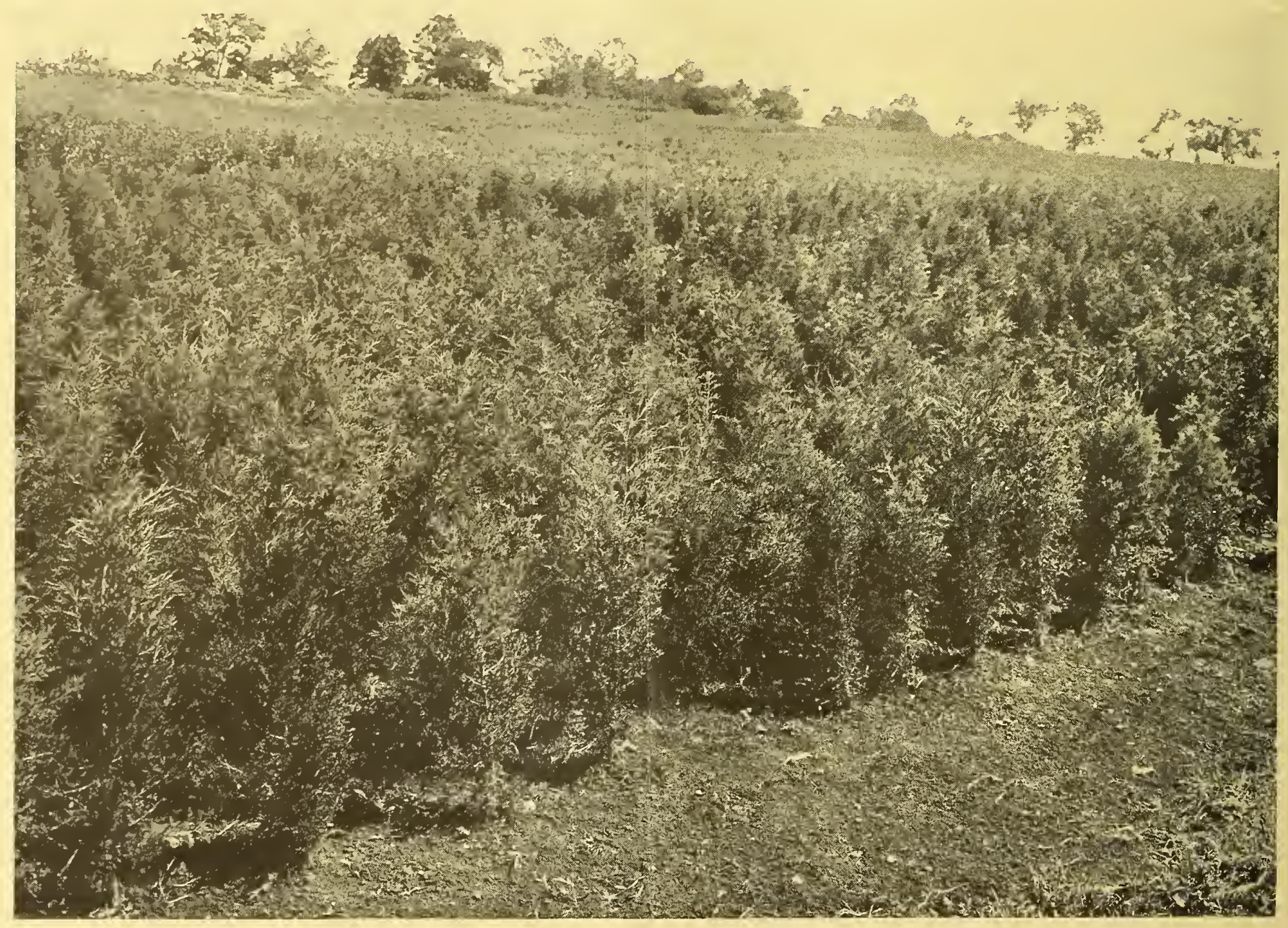

ONE OF OUR FINE BLOCKS OF TWICE-TRANSPLANTED JUNIPERS 2 TO 3 FEET IIGH. WHERE DISTINCTIVENESS IS DESIRED JUNIPERS ARE EXTREMELY EFFECTIVE USED SINGLY, IN GROUPS, AND WITH OTHER KINDS OF TREES 


\section{Prices in Lots of \\ $10 \quad 100 \quad 1,000$ \\ European Larch}

LARIX EUROPEA, D. C.

Three Times Transplanted 5 to $6 \mathrm{ft}$. Three Times Transplanted 4 to $5 \mathrm{ft}$. Three Times Transplanted 3 to $4 \mathrm{ft}$.

Three Times Transplanted 2 to $3 \mathrm{ft}$.

LARIX LEPTOLEPSIS, Gord.

Transplanted.

$1 \frac{1}{2}$ to $2 \frac{1}{2} \mathrm{ft}$.

Transplanted 1 to $1 \frac{1}{2} \mathrm{ft}$.

LARIX SIBERICA, Led.

Seedling .......... 3 to 6 in.

Seedling

1 to 3 in.

$8.00 \quad 40.00$

$6.00 \quad 30.00$

$4.00 \quad 20.00$

Japanese Larch

$\$ 2.00 \$ 10.00$

$1.50 \quad 8.00$

Siberian Larch

$\$ 3.00 \quad \$ 25.00$

$2.00 \quad 17.00$

\section{HEIGH'T}

PICEA ALBA, Link.

Twice Transplanted

Twice Transplanted

Transplanted

Seedling

Seedling
Prices in Lots of

$10 \quad 100 \quad 1,000$

White Spruce
White Spruce is a rapid grower of a pyramidal shape and much admired for its silvery green, refreshing foliage. It is very hardy, adapting itself to both wet and dry soils and perfectly withstanding salt air exposure and snow and ice pressure. It is thus a very much used tree for planting near the sea, and also for windbreaks, screens, groves and specimen trees. The wood is valuable both for lumber and for paper pulp. Our trees are grown from seed from the Maine coast, where the species reaches fine development.

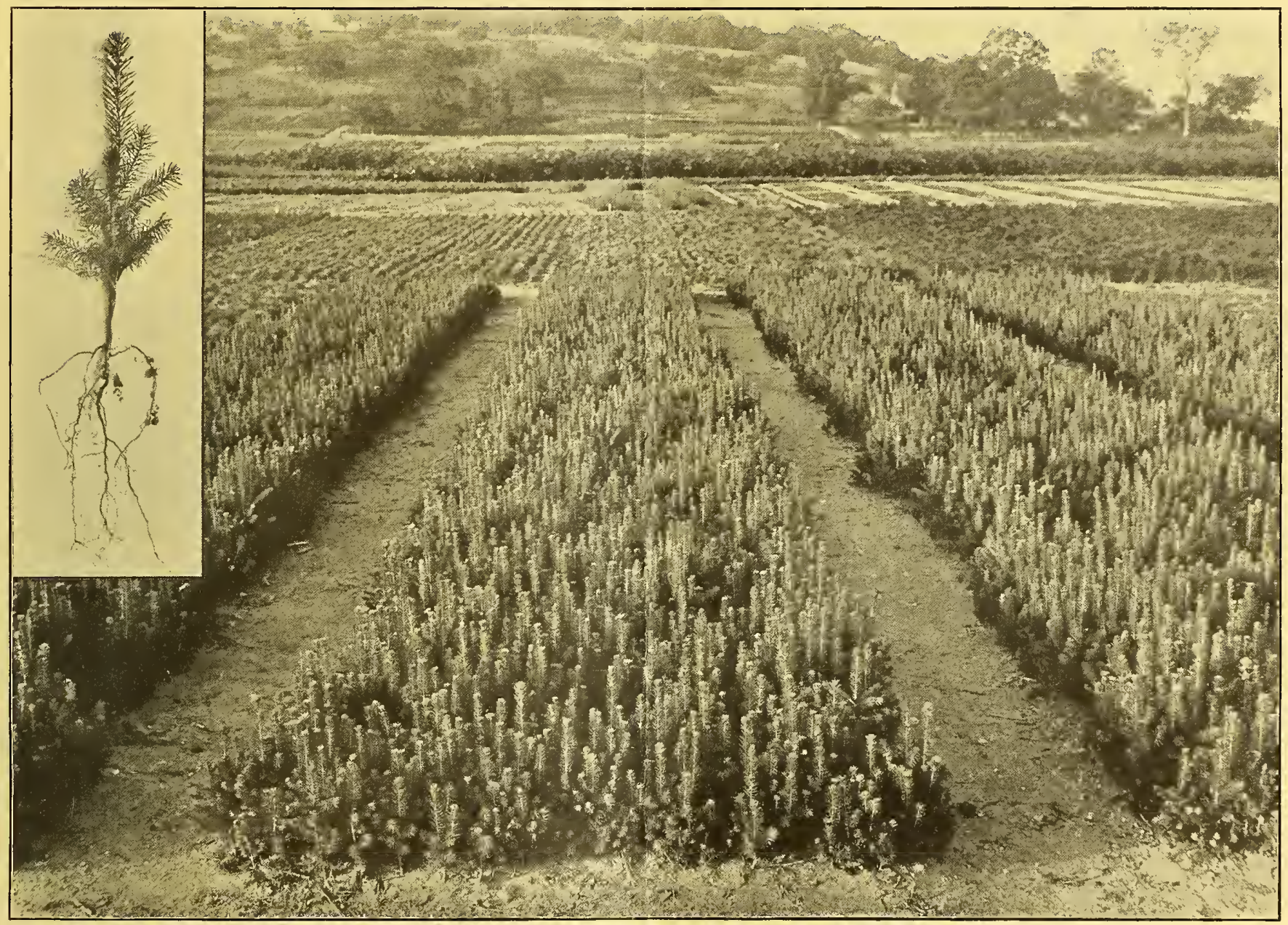

White Spruce in Seedling Beds four feet wide, fifty feet long, perfectly grown, splendidly rooted. Sample tree in corner. 
PICEA ENGELMANNI, Englm.
Engelmann Spruce

TRANSPLANTED

Prices in Lots of

HEIGHT $\quad 10 \quad 100 \quad 1,000$

8 to 12 in. $\$ 1.50 \$ 7.00$

4 to $8 \mathrm{in.} \quad 1.00 \quad 5.00$

SEEDLING

t to 8 in. $\quad \$ 2.50 \quad \$ 15.00$

$Q$ to $t$ in. $\quad 1.50 \quad 8.00$

NORWAY 'SPRUCE

The Spruce of Europe

A merican-Born
and
American-Grown

The Norway Spruce is grown every where in Europe for a multitude of purposes. The wood is valuable and has many uses. In this country it is largely used for hedges, screens, windbreaks and shelter belts. It is extremely hardy and can be planted in the shade. It is a very rapid grower.

Recently extensive Norway spruce forests have been planted to meet the coming demand for paper pulp.

\section{PLANT NORWAY SPRUCE} FOR A CROP OF

\section{CHRISTMAS TREES}

We can strongly recommend a plantation for a crop of Christmas trees to be sold with or without roots.

PICEA EXCELSA, L. K'

Twice Transplanted

Twice Transplanted

Twice Transplanted

Twice Transplanted

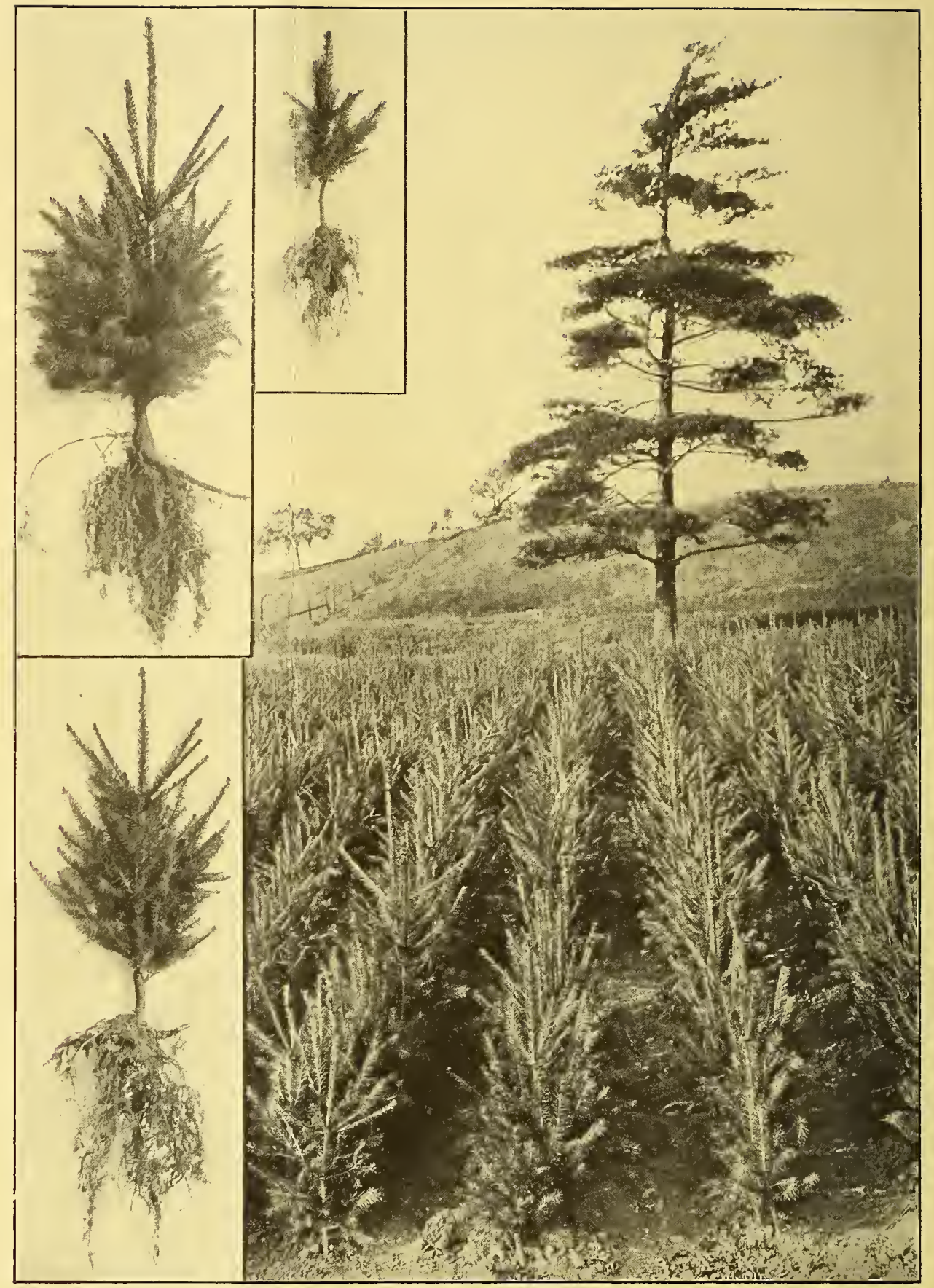

NORWAY SPRUCE AS WE GROW IT AT Jittle Trep Farma uf Antrrira. NOTE THE FIBROUS ROOT SYSTEMS AND GENERAL STOGKINESS OF THE INDIVIDUAL PLANTS.

2 to $3 \mathrm{ft} . \$ 4.00 \$ 20.00 \$ 160.00$

$\begin{array}{lrrr}1 \frac{1}{2} \text { to } 2 \mathrm{ft} . & 3.00 & 14.00 & \mathbf{1 1 5 . 0 0}\end{array}$

1 to $1 \frac{1}{2} \mathrm{ft}$. $1.80 \quad 9.00 \quad 75.00$

8 to 12 in. $\quad 1.00 \quad 5.00 \quad \$ 0.00$
Transplanted.

Transplanted.
HEIGHT

8 to 12 in.

+ to $8 \mathrm{in}$.
Prices in Lots of $100 \quad 1,000$ $\$ 3.00$

$2.00 \$ 14.00$ 


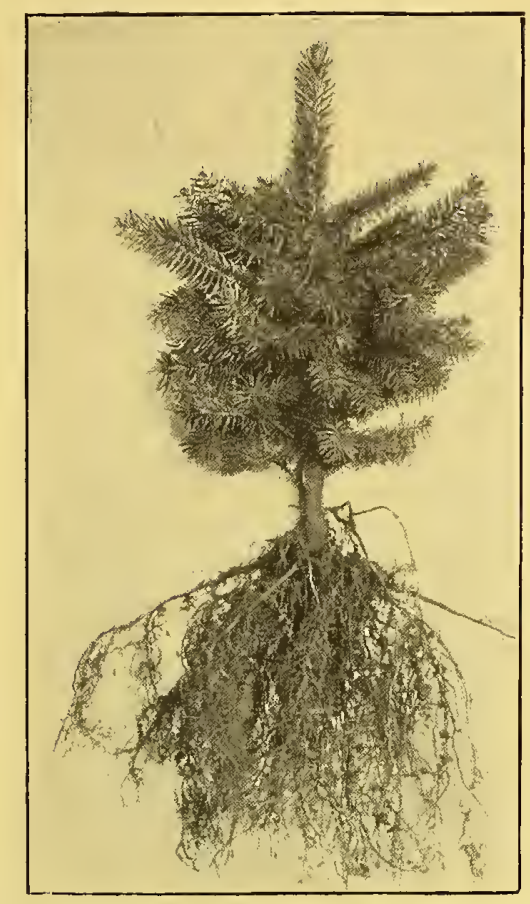
RADO BLUE SPRUCE FROM Tittle đrpp Tfarms

HEIGHT Prices in Lots of Colorado Blue Spruce

PICEA PUNGENS, Engl.

12 to $15 \mathrm{in}$. $\$ 3.00 \$ 15.00$

Transplanted

Transplanted

Transplanted

8 to 12 in

$1.60 \quad 8.00$

+ to 8 in.

5.00

40.00

PICEA RUBENS, Sarg.

Twice Transplanted

Twice Transplanted

8 to $12 \mathrm{in}$.

Red Spruce

Transplanted

Transplanted

+ to 8 in

$\$ 1.2 .5 \$ 6.00$

4.50

$3.00 \$ 20.00$

8 to 12 in.

+ to 8 in.

\section{HEIGH'T}

PINUS FLEXILIS, James.

Seedling

Seedling

6 to 9 in.

+ to 6 in.

PINUS LARIGIO, Poir

Seedling

$+10 \quad 8$ in

PINUS MONTICOLA, Dougl

Seedling

? $10+$ int.

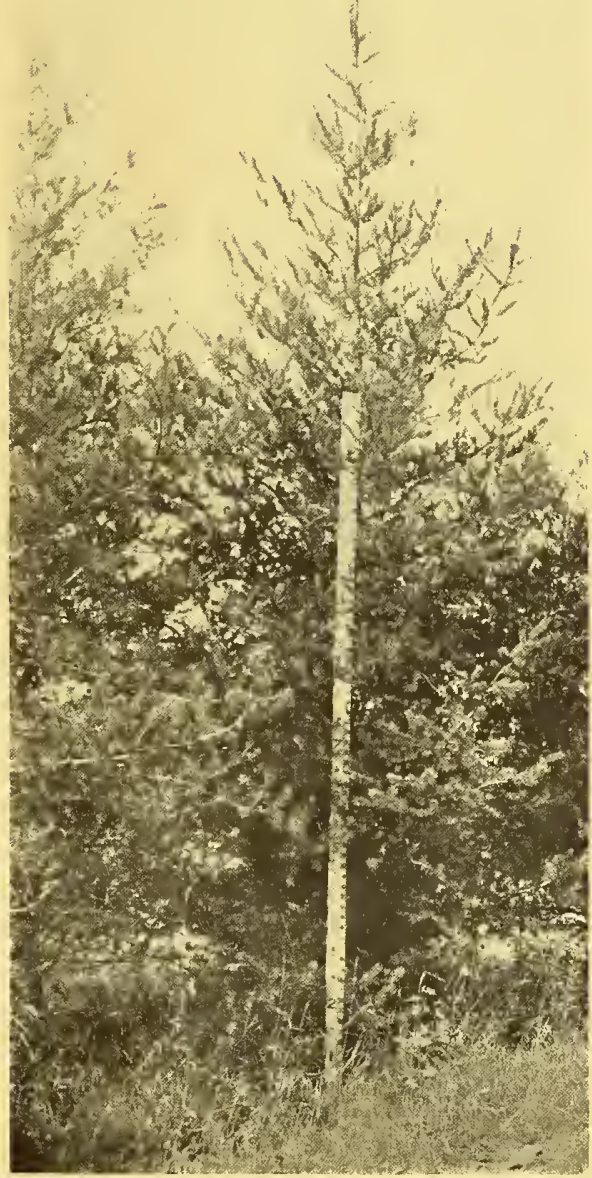

A Glimpse at a Plantation of Bank's Pine, avera ing 23 feet high, 10 years after being set out by Mr. Borst, Forest Engineer of the American Forestry Company.
Prices in Lots of $10 \quad 100 \quad 1,000$ Limber Pine

$\$ 2.50 \$ 15.00$ $2.00 \quad 10.00$

Corsican Pine $\$ 2.00 \quad \$ 12.00$

Silver or Western White Pine

$\$ 1.7 .5 \$ 12.00$

$$
\text { Use Red Spruce for planting in shady places. }
$$

PINUS DIVARICATA, DuMont.

Bank's Pine

Three Times Transplanted + to $6 \mathrm{ft}$. $\$ 5.00 \$ 30.00 \quad \$ 225.00$ Twiee Transplanted 4 to $6 \mathrm{ft}$. $4.00 \quad 20.00$

65.00 Seedling 6 to 10 in.

$2.00 \quad 14.00$

Bank's Pine, known also as the "sudden sawlog," is especially" recommended for immediate effeets. It is the hardiest native evergreen tree in America. It thrives on the poorest, driest soils and in the most exposed places. It is an admirable nurse tree for slower-growing evergreens 


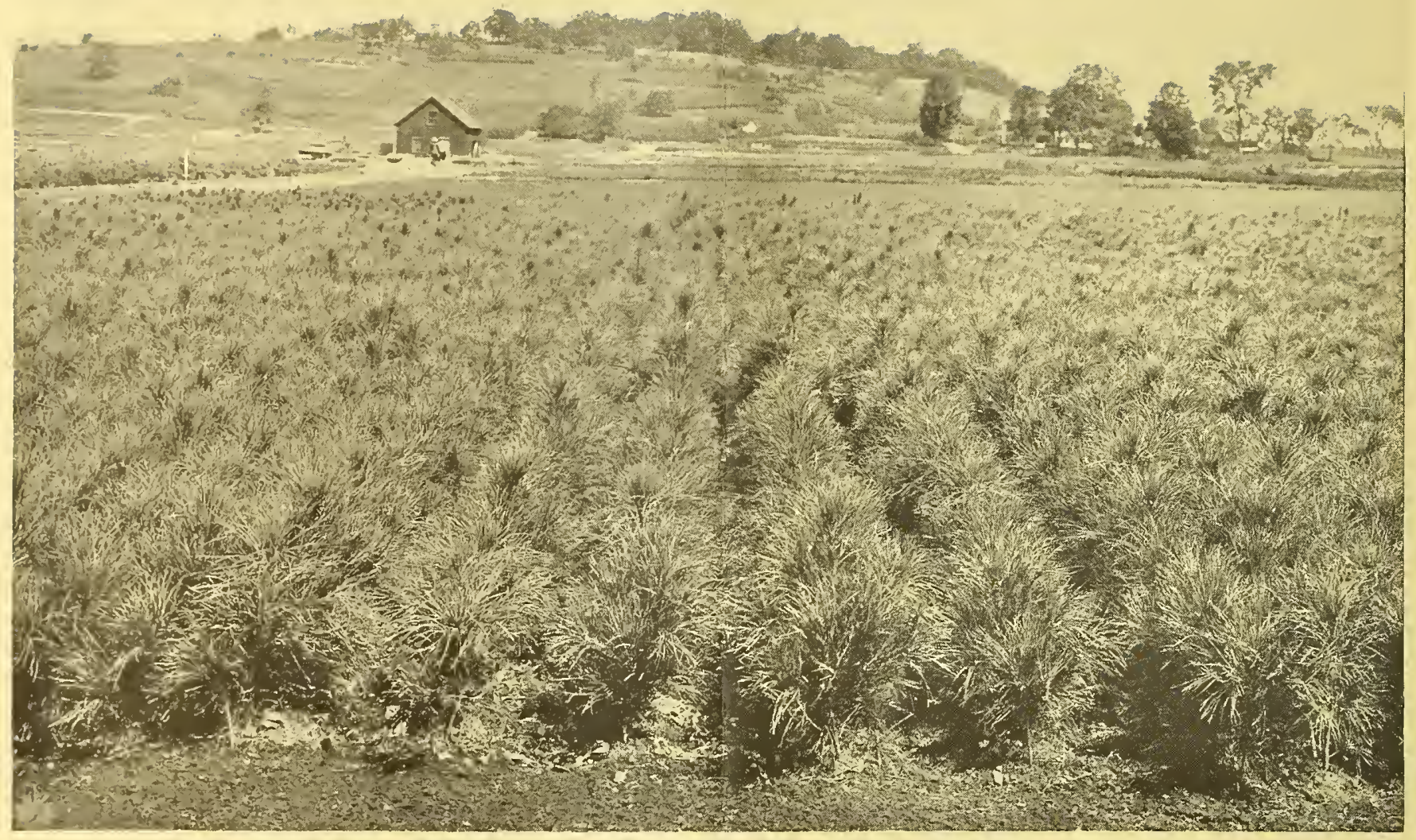

ROWS OF TRANSPLANTED RED PINES 1 TO $1 \frac{1}{2}$ FEET HIGH AT Tittle Tre Ifarmt uf Amerira

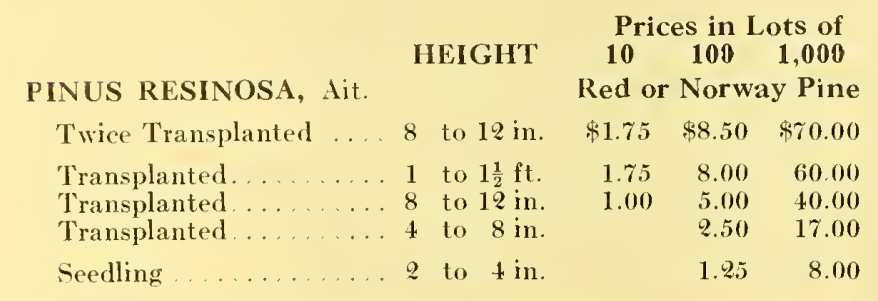

The Red or Norway Pine (Pinus resinosa) is one of the most valuable native trees for general planting: It grows faster than the White Pine and makes a fine combination with this tree.

It withstands salt air and spray as few other trees do. It grows where grass and other agricultural crops are not profitable. It is picturesque even on poor soils, and on richer soils it has a vigorous and superb growth of long. deep green needles. The wood of this species is valuable and is being more

appreciated every year.
Its comparative freedom from insect and fungous enemies is a very valuable charaoteristic of the Red Pine.

There has been a very limited supply of this species for several years, and substitution of other kinds has been known. Our Red Pines are GUARAN TEED TRUE RESINOSA. Although Red Pine seed is high, these plants are extremely cheap, and nurserymen who visit our nurseries are glad to buy them at sight. The trees we have at present are wonderfully well rooted and developed. (See illustration of individual Red Pine on Page 15.)

\section{HEIGHT}

PINUS RIGIDA, Mill.

Transplanted.

8 to 19 in.

Prices in Lots of $10100 \quad 1,000$ Pitch Pine

$\$ 2.50 \$ 17.00$

PINUS STROBUS, Linn.

Twice Transplanted Twice Transplanted Twice Transplanted Twice Transplanted

Transplanted

Transplanted

Transplanted

Seedling

3 to $4 \mathrm{ft}$

2 to $3 \mathrm{ft}$.

$1 \frac{1}{2}$ to $2 \mathrm{ft}$.

1 to $1 \frac{1}{2} \mathrm{ft}$.

2 to $2 \frac{1}{2} \mathrm{ft}$.

$1 \frac{1}{2}$ to $2 \mathrm{ft}$.

1 to $1 \frac{1}{2} \mathrm{ft}$.

4 to 6 in.

$\$ 7.00 \$ 35.00 \$ 325.00$

$\begin{array}{lll}4.50 & 23.00 & 190.00\end{array}$

$\begin{array}{lll}2.25 & 12.00 & 90.00\end{array}$

$\begin{array}{lll}1.75 & 9.00 & 70.00\end{array}$

$2.00 \quad 9.00 \quad 75.00$

$\begin{array}{lll}1.50 & 7.00 & 50.00\end{array}$

$1.00 \quad 4.00 \quad 30.00$

(See illustrations of White Pine on Pages 12, 13 and 14.) 
Prices in Lots of
HEIGHT
$10 \quad 100 \quad 1,000$

PINUS SYLVESTRIS, A.

Twice Transplanted $\quad 3$ to $4 \mathrm{ft}$.

Transplanted

Transplanted

1 to $1 \frac{1}{2} \mathrm{ft}$

8 to 12 in

$4.50 \quad 22.00$

$4.00 \$ 30.00$

2.50

18.00

PSEUDOTSUGA TAXIFOLIA, Britt. syn. DOUGLASII, Carr.

Transplanted

Transplanted

Transplanted

Seedling

Seedling

1 to $1 \frac{1}{2} \mathrm{ft}$.

8 to 12 in.

4 to 8 in

8 to $12 \mathrm{in}$.

4 to 8 in.

Douglas Spruce

(Rocky Mountain Seed)

$\$ 1.50 \quad \$ 6.00 \quad \$ 45.00$

$\begin{array}{rrr}1.00 & 4.00 & 30.00\end{array}$

$2.00 \quad 15.00$

$2.00 \quad 14.00$

$1.25 \quad 7.00$

Douglas Spruce is one of the most majestic trees of North Ameriea, and although one of the fastest growing evergreens, is long lived and attains a large size. In gracefulness it resembles the Hemlock. The wood is valuable It is taking rank as the chief spruce for ornamental and forestry planting in the East. It is uncommonly hardy, succecding on dry, slaty and sandy the East. It is uncommonly hardy, succecding on dry, slaty and sandy
soils and in direct exposure to fierce winds and to salt spray. Our plants are well topped, well rooted and straight. Those who visit out nurseries order them at sight
Three Times Transplanted 4 to $5 \mathrm{ft}$.

$\$ 8.00 \$ 40.00$

Prices in Lots of

HEIGHT Each $10 \quad 100$

TAXUS GUSPIDATA BREVIFOLIA. Several Times Transplanted $\mathcal{2}$ to $2 \frac{1}{\mathrm{ft}}$. Several Times Transplanted 1 to $1 \frac{1}{2} \mathrm{ft}$. Several Times Transplanted 6 to $12 \mathrm{in}$. Several Times Transplanted 4 to 6 in.

TAXUS REPANDENS.

Several Times Transplanted 1 to $1 \frac{1}{2} \mathrm{ft}$. Several Times Transplanted 6 to $10 \mathrm{in}$. Several Times Transplanted 4 to $6 \mathrm{in}$.

THUJA OGCIDENTALIS, Linn.

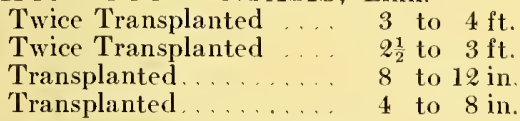
Japanese Yew $\$ 3.50 \$ 32.50$

$\begin{array}{lll}1.75 & 16.00 & \$ 140.00\end{array}$

$\begin{array}{lll}1.25 & 11.00 \quad 90.00\end{array}$

$\begin{array}{lll}90 & 7.50 \quad 60.00\end{array}$

Spreading Yew

$\$ 1.00 \quad \$ 9.00 \quad \$ 80.00$

$\begin{array}{lll}70 & 6.00 & 50.00\end{array}$

$50 \quad 4.00 \quad 35.00$

Arborvitae: Cedar $\$ 10.00 \$ 5.00$ $6.00 \quad 35.00$

$1.00 \quad 6.00$

The American Arborvitae (White Cedar) is mueh used for hedges and sereens as well as for single specimens. It is hardy, transplants easily, and grows rapidly, soon forming a very dense growth. It makes a highly ornamental screen for dividing the lawn from other parts of the estate. It grows well on lands too wet for most trees. (See illustration of individual Arborvitae
on Page 15.)

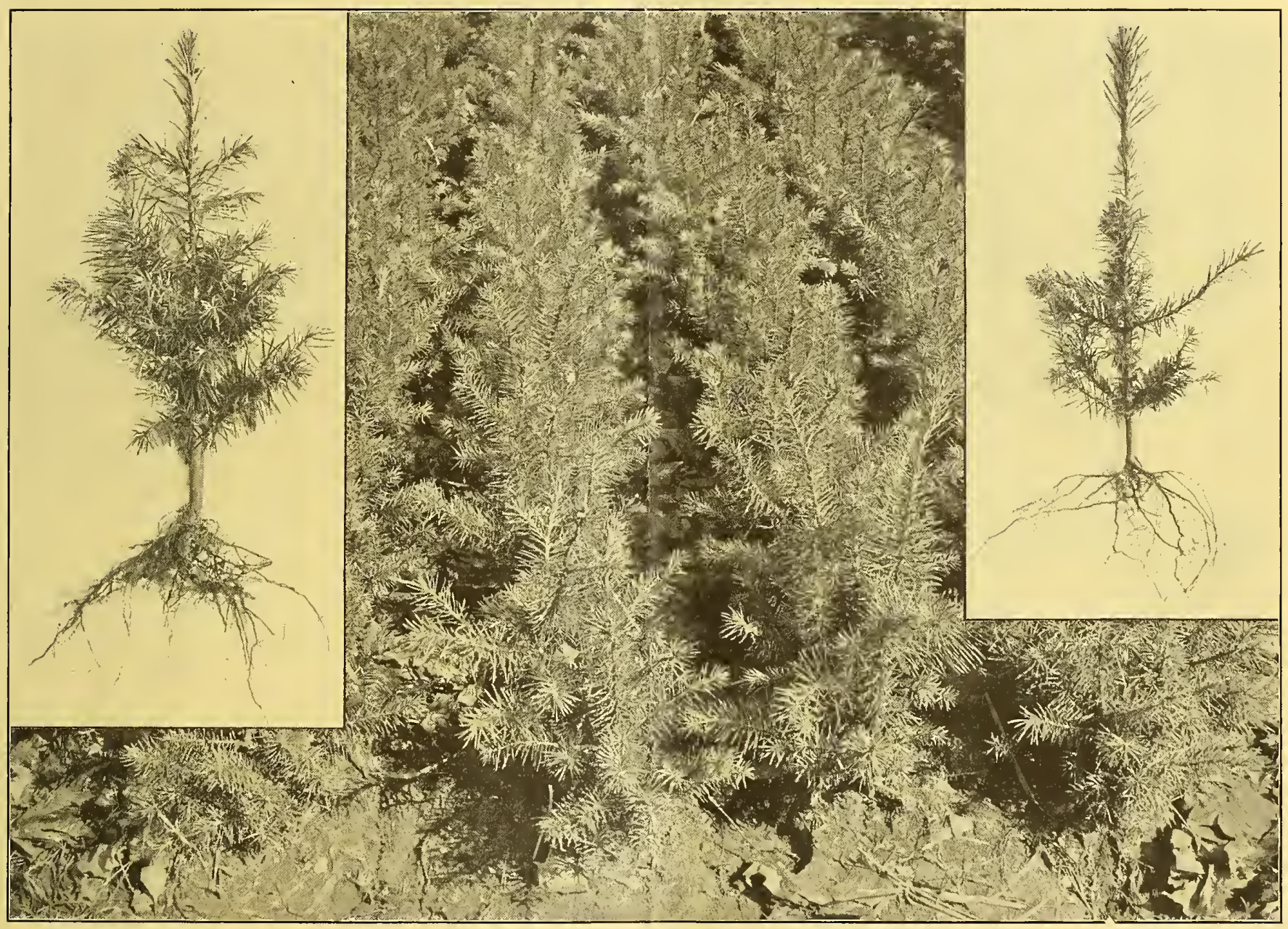

Close View of Seedling Beds of Douglas Spruce at IIttle Cre Ifarmts. Individual Seedling in right corner and small Transplant at left. Our Douglas Spruce are raised from Rocky Mountain Colorado Seed and are perfectly Hardy and Vigorous. 



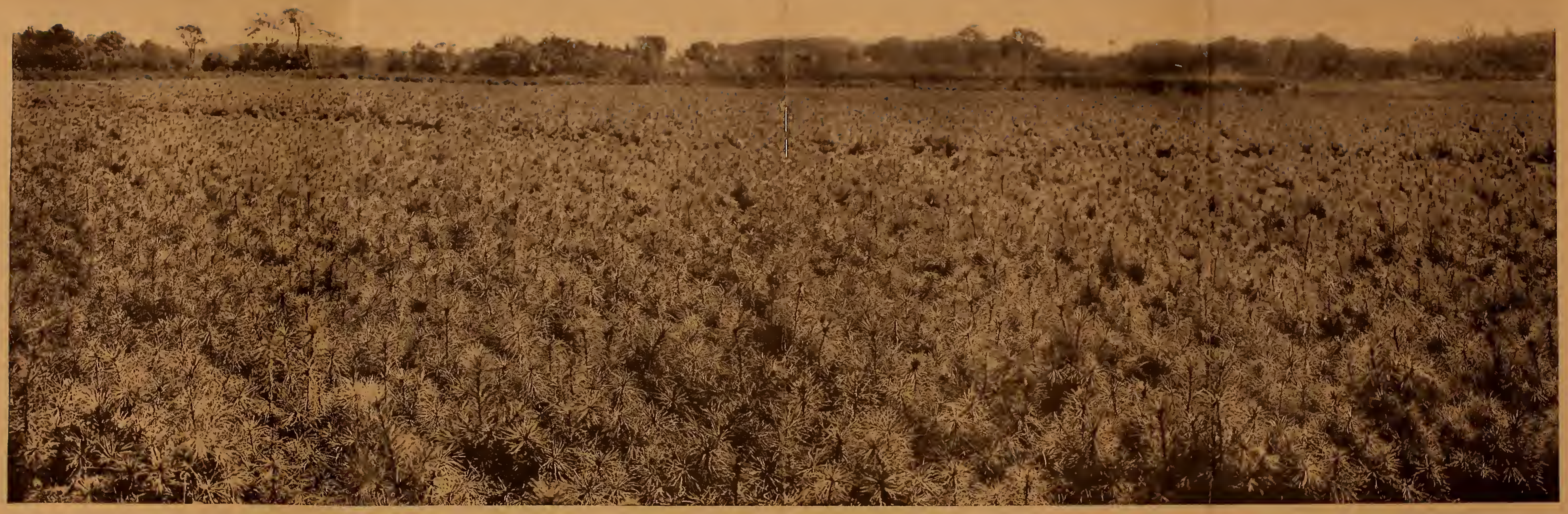

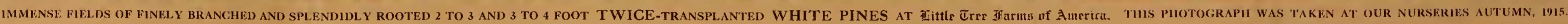

\section{WHITE PINE}

AMERICA'S GREATEST COMMERCIAL TREE

Plant White Pine for Profit

Use White Pine for cul-over lands, for sandy soils and other bare, unproductive, unsiglitly places, for worn-out pas. tures, for land useless for other purposes. Use White Pine to increase the value of country building sites; for underplanting in shady places; in woods where chestnut trees ve died ou

Buy waste land; plant it to White Pine; it will pay you. White Pine has an especially large volume of body wood. grows dense and thus "cleans itself" from all old dead limbs comparatively well. This is conducive to lumber that straight-grained and free from knots.

\begin{tabular}{|c|c|c|c|}
\hline TWICE. & $\begin{array}{l}\text { 3 to } 4 \\
\text { FEET }\end{array} 325$ for 1000 & $\$ 35$ for 100 & $\begin{array}{l}10 \text { Trees } \\
\text { for } \$ 7.00\end{array}$ \\
\hline $\begin{array}{l}\text { Transplanted } \\
\text { BUSHY STOCKY } \\
\text { HARDY VIGOROUS }\end{array}$ & FEET $\$ 190$ for 1000 & $\$ 23$ for 100 & $\begin{array}{l}10 \text { Trees } \\
\text { for } \$ 4.50\end{array}$ \\
\hline WHITE & 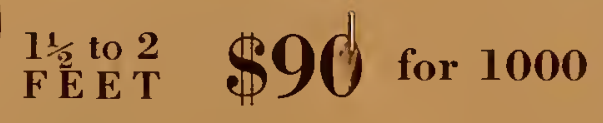 & $\$ 12$ for 100 & $\begin{array}{l}10 \text { Trees } \\
\text { for } \$ 2.25\end{array}$ \\
\hline$P 1$ & $\begin{array}{l}1 \text { to } 1 \frac{1}{2} \$ 70 \text { for } 1000 \\
\text { FEET }\end{array}$ & $\$ 9$ for 100 & $\begin{array}{l}10 \text { Trees } \\
\text { for } \$ 1.75\end{array}$ \\
\hline
\end{tabular}

FOR SUCCESS PLANT OUR TWICE-TRANSPLANTED WHITE PINES
WHITE PINE

AMERICA'S GREATEST ORNAMENTAL TREE

Plant White Pine for Beauty

Use White Pine for screens, roadside borders and backtrounds, avenue planting and otherwise beautifying an estate. . The is nothing 政 cool, refreshing seclusion of a pine grove with its soft carpet of needles.

White Pine soon gives a good cover for a shooting preserve. A new grove of White Pine laid out with pleasan avenues and drives is a source of interest and pleasure from the very start and becomes in a few years a most desirable feature of a country home. 


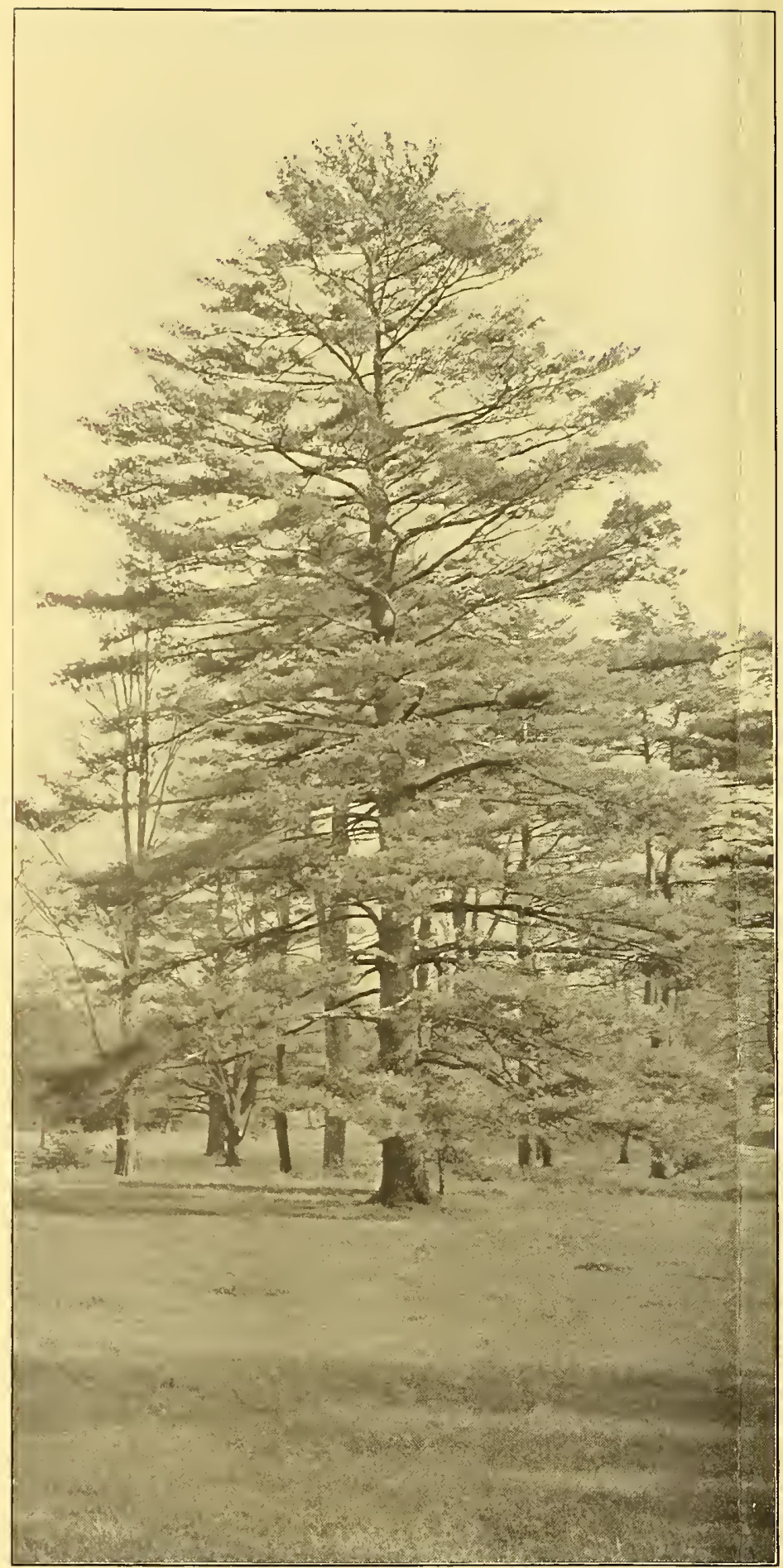

\section{White Pine The King of American Evergreens} "The Very Foundation of Ornamental and Commercial Tree Planting"

\section{W}

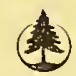
you not give to have beautiful Pines in full maturity, like the one illustrated on this page, beau. tifying your home grounds? White Pine plants easily and grows rapidly. Don't delay. Make a start this spring by planting some of our sturdy TwiceTransplanted White Pines. It will be a constant pleasure to watch the remarkable annual growth of these trees. 


\section{TWICE-TRANSPLANTED Trees}

Transplanting produces general stockiness and an abundance of fibrous roots. Trees that have

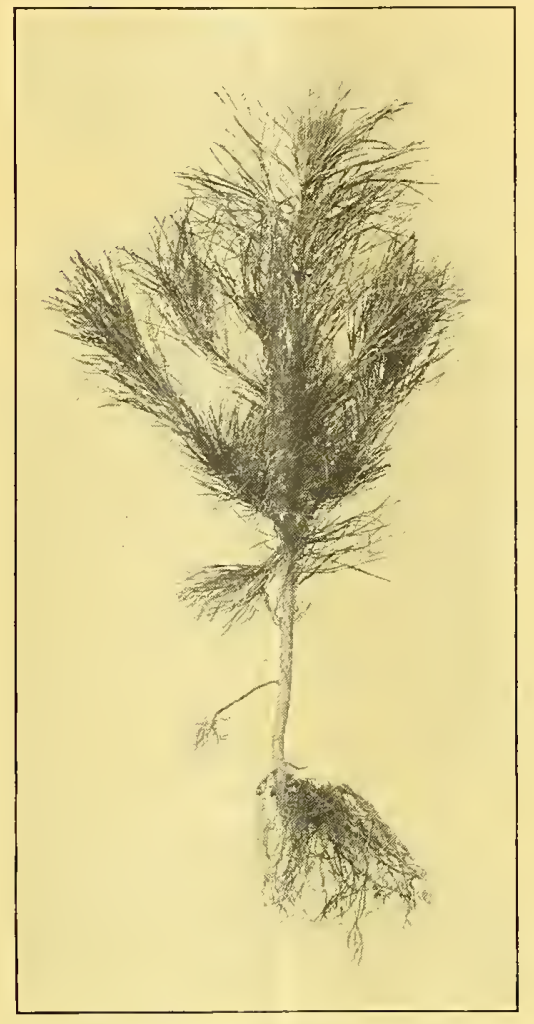

One of our Transplanted 1 1/2 Foot Red Pines

been transplanted are more enduring and make faster growth than those that have not.

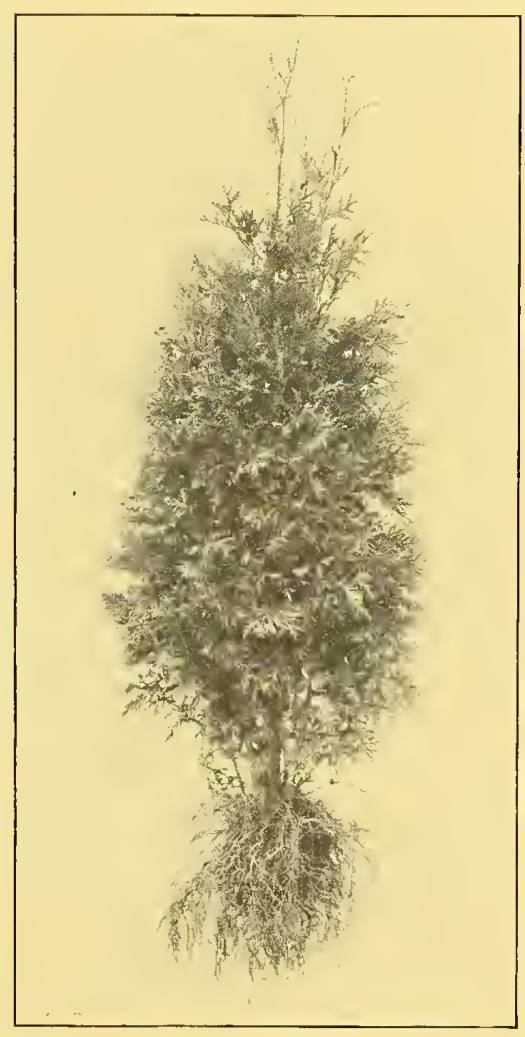

One of our Twice-Transplanted 3 Foot Arborvitae 


\section{BROAD-LEAVED TREES (Deciduous)}

AND SOME SHRUBS, ETC.

We annually grow large quantities of these trees in many varieties.

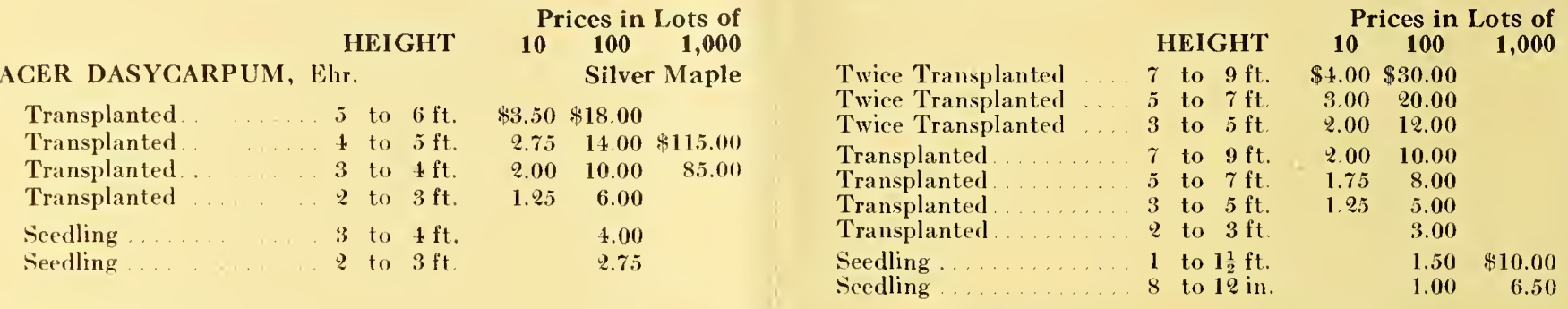

ACER NEGUNDO, Lim.

Three Times Transplanted 9 to $12 \mathrm{ft}$.

Three, Times Transplanted $\gamma$ to $9 \mathrm{ft}$.
Box Elder

$\$ 6.00$

$5.00 \$ 40.00$
Use Box Elder for fast growing, comparatively dense screens for buildings, etc. Acer Negundo, Box Elder, is used a great deal as a substitute for Poplars. It grows almost as rapidly and more dense.

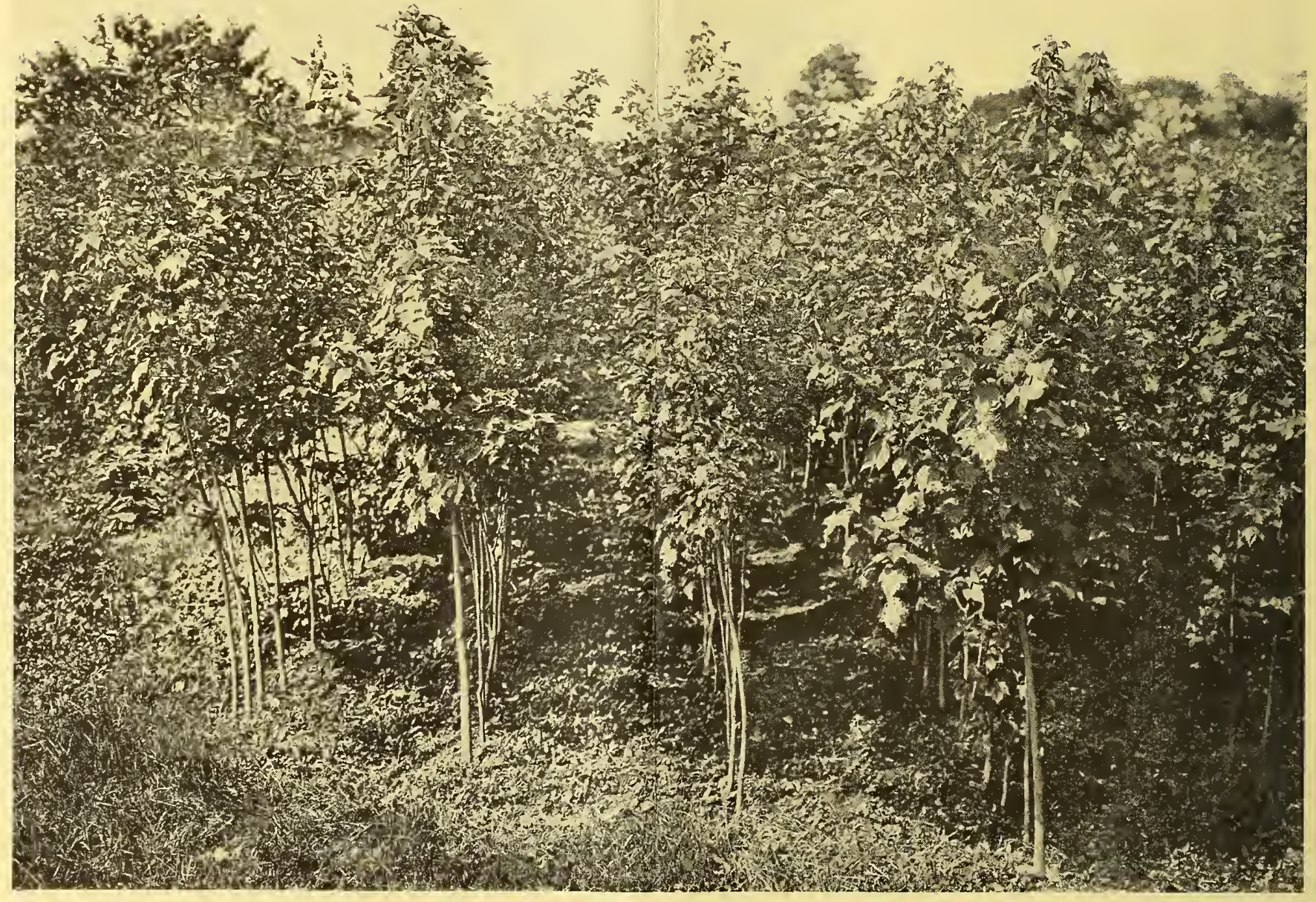

A BLOCK OF OUR RED MAPLES IN FULL AUTUMN FOLIAGE 


\section{ACER PLATANOIDES, Linn}

Twice Transplanted

Twice Transplanted

Transplanted

Transplanted

Transplanted

Transplanted

Seedling

Seedling

\section{4 to $6 \mathrm{ft}$.}

2 to $3 \mathrm{ft}$

4 to $5 \mathrm{ft}$.

3 to $4 \mathrm{ft}$.

2 to $3 \mathrm{ft}$.

1 to $2 \mathrm{ft}$.

2 to $3 \mathrm{ft}$.

1 to $2 \mathrm{ft}$

\section{ACER PSEUDO-PLATANUS, Linn.}

\section{Transplanted}

Transplanted

Transplanted

Seedling

Seedling

3 to $4 \mathrm{ft}$
2 to $3 \mathrm{ft}$.
1 to $2 \mathrm{ft}$
8 to $12 \mathrm{in}$.
+ to $8 \mathrm{in}$.

Prices in Lots of

$10 \quad 100 \quad 1,000$

Norway Maple

$\$ 3.00 \$ 15.00$

$1.80 \quad 9.00$

$2.00 \quad 10.00$

$\begin{array}{lll}1.50 & 6.50 & \$ 50.00\end{array}$

$1.00 \quad 5.00 \quad 40.0$ !

$3.00 \quad 20.00$

$2.50 \quad 17.00$

$2.00 \quad 12.00$

Sycamore Maple

$\$ 1.75 \$ 8.00$

$1.00 \quad 5.00$

3.00

1.25

.90
ACER RUBRUM, Linn

Twice Transplanted

Transplanted

Transplanted

Transplanted

Transplanted

\section{HEIGHT}

Prices in Lots of

$10 \quad 100 \quad 1,000$ Red Maple

+ to $5 \mathrm{ft}$

6 to $8 \mathrm{ft}$.

4 to $6 \mathrm{ft}$

3 to $4 \mathrm{ft}$.

2 to $3 \mathrm{ft}$

$\$ 3.00 \$ 15.00 \$ 130.00$

$\begin{array}{lll}3.50 & 18.00 & 160.00\end{array}$

$2.50 \quad 12.00 \quad 100.00$

$\begin{array}{rrr}2.00 & 10.00 & 90.00 \\ 1.50 & 7.50 & 65.00\end{array}$

(See illustration of Red Maples on Page 16.)

ACER SACGHARUM, Marsh.

Sugar Maple

Transplanted.

Transplanted

Transplanted

Seedling

Seedling
3 to $4 \mathrm{ft}$

2 to $3 \mathrm{ft}$

1 to $2 \mathrm{ft}$

8 to 12 in.

4 to 8 in.
$\$ 3.00 \$ 15.00 \$ 130.00$

$2.00 \quad 10.00 \quad 85.00$

$\begin{array}{lll}1.00 & 5.00 \quad 40.00\end{array}$

$2.00 \quad 12.00$

$1.25 \quad 6.50$

The Sugar or Rock Maple is one of the most popular avenue trees, and is also much used for shade in lawns and parks. Maple sugar is principally made from this tree. It is remarkably free from the attacks of destructive insects. Our Sugar Maples are extremely hardy and are grown from seed collected by our own men in our region. We find this elegant tree to be one of the most popular of the hardwoods.

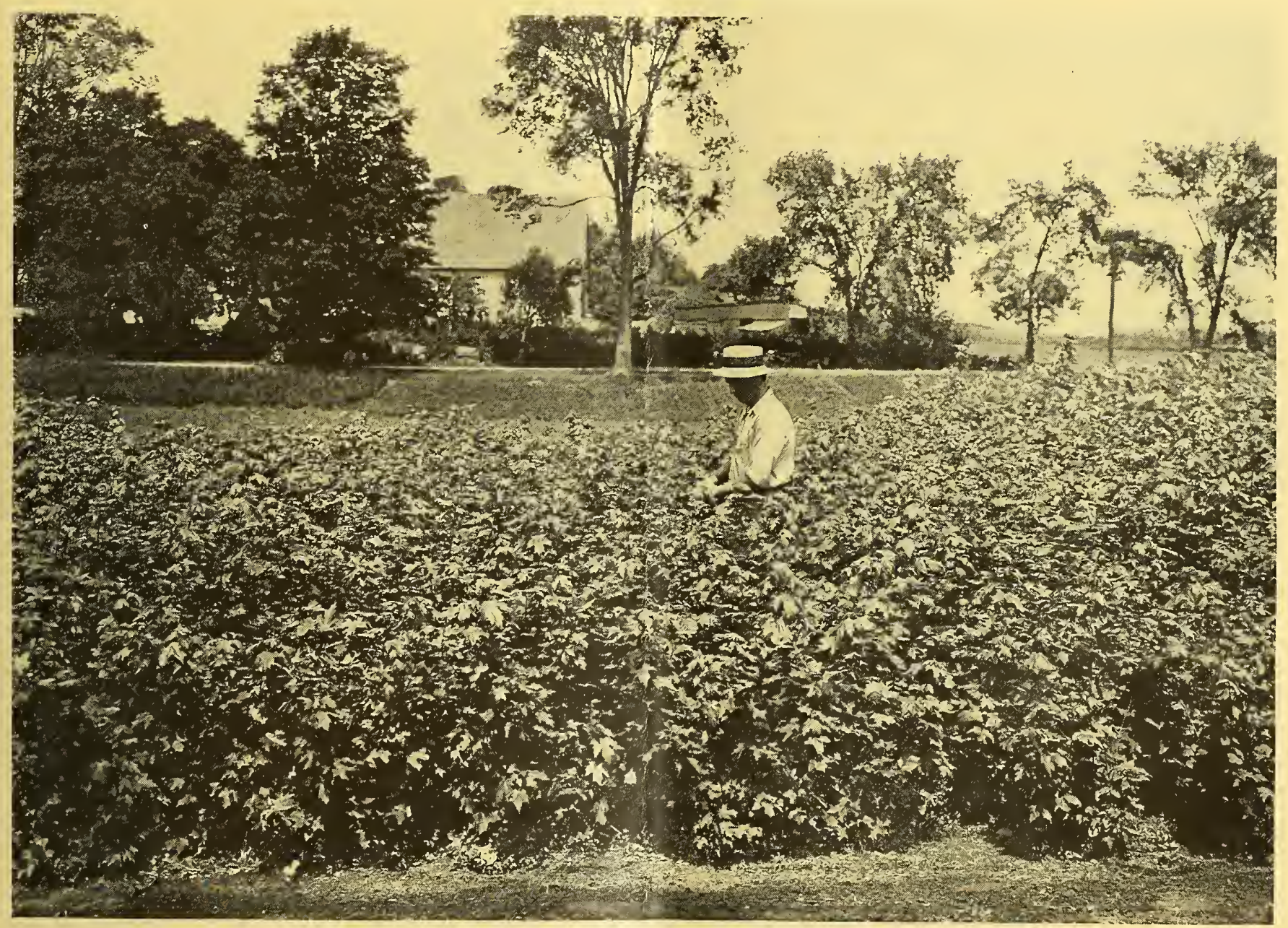

A LARGE BLOCK OF YOUNG SUGAR MAPLES GROWING AT Tittle Crre Jfarme 


\section{AESGULUS GLABRA, Willd.}

Twice Transplanted ... 8 to $12 \mathrm{in}$. Transplanted........ 1 to $2 \mathrm{ft}$.

BETULA ALBA, Linn.

Seedling .........2 to $3 \mathrm{ft}$. Seedling ............ Seedling .......... 8 to 12 in. Seedling ........... t to $8 \mathrm{in}$.

BETULA LENTA, Linn,

Seedling $\ldots \ldots \ldots \ldots \ldots \ldots$ \& to $3 \mathrm{ft}$.
Seedling $\ldots \ldots \ldots \ldots \ldots$ to $2 \mathrm{ft}$.
Seedling $\ldots \ldots \ldots \ldots \ldots$ to $12 \mathrm{in}$.

BETULA LUTEA, Michx.

Twice Transplanted ...4 4 to $5 \mathrm{ft}$. Transplanted......... \& to $3 \mathrm{ft}$. Transplanted......... 1 to $\mathbf{q} \mathrm{ft}$.

BETULA PAPYRIFERA, Marsh.

Transplanted.......... t to $5 \mathrm{ft}$. Transplanted........ 3 to $4 \mathrm{ft}$.

\section{CARPINUS BETULUS, Linn.}

Seedling .......... 1 to $2 \mathrm{ft}$. Seedling ........... 8 to $12 \mathrm{in}$.

CATALPA SPECIOSA, Warder.

True Hardy or Western

Three Times Transplanted $\gamma$ to $9 \mathrm{ft}$. Twiee Transplanted .... \& to $3 \mathrm{ft}$. Seedling

1 to $2 \mathrm{ft}$.

\section{CORNUS PANIGULATA.}

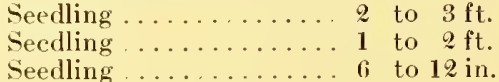

$$
\begin{array}{rrr}
\$ 4.00 & \multicolumn{2}{c}{\text { Catalpa }} \\
1.00 & \$ 4.50 & \\
& 1.00 \quad \$ 7.00
\end{array}
$$

Gray Dogwood $\$ 3.00 \$ 15.00$

$\begin{array}{lll}1.75 & 9.00 & \$ 80.00\end{array}$ $1.00 \quad 5.00 \quad 40.00$

\section{GORYLUS AMERICANA.}

Seedling .......... 1 to $1 \frac{1}{2} \mathrm{ft}$. Seedling ......... 8 to 12 in.

GRATAEGUS GOCGINEA, Linn.

Seedling .......... 8 to $12 \mathrm{in}$. Seedling .......... 4 to 8 in.

FRAXINUS AMERIGANA, Linn. True Eastern White Ash

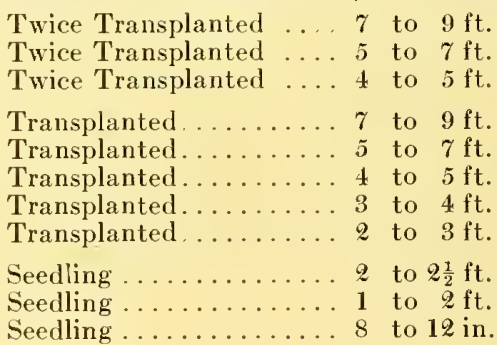

$\$ 4.00 \$ 20.00$

$3.00 \quad 15.00$

$2.00 \quad 10.00 \quad \$ 90.00$

$2.50 \quad 12.00$

$2.00 \quad 9.00$

$1.50 \quad 7.00$

$1.25 \quad 6.00$

$1.00 \quad 4.50$

$2.00 \quad 15.00$

$1.50 \quad 13.50$

$1.00 \quad 7.00$

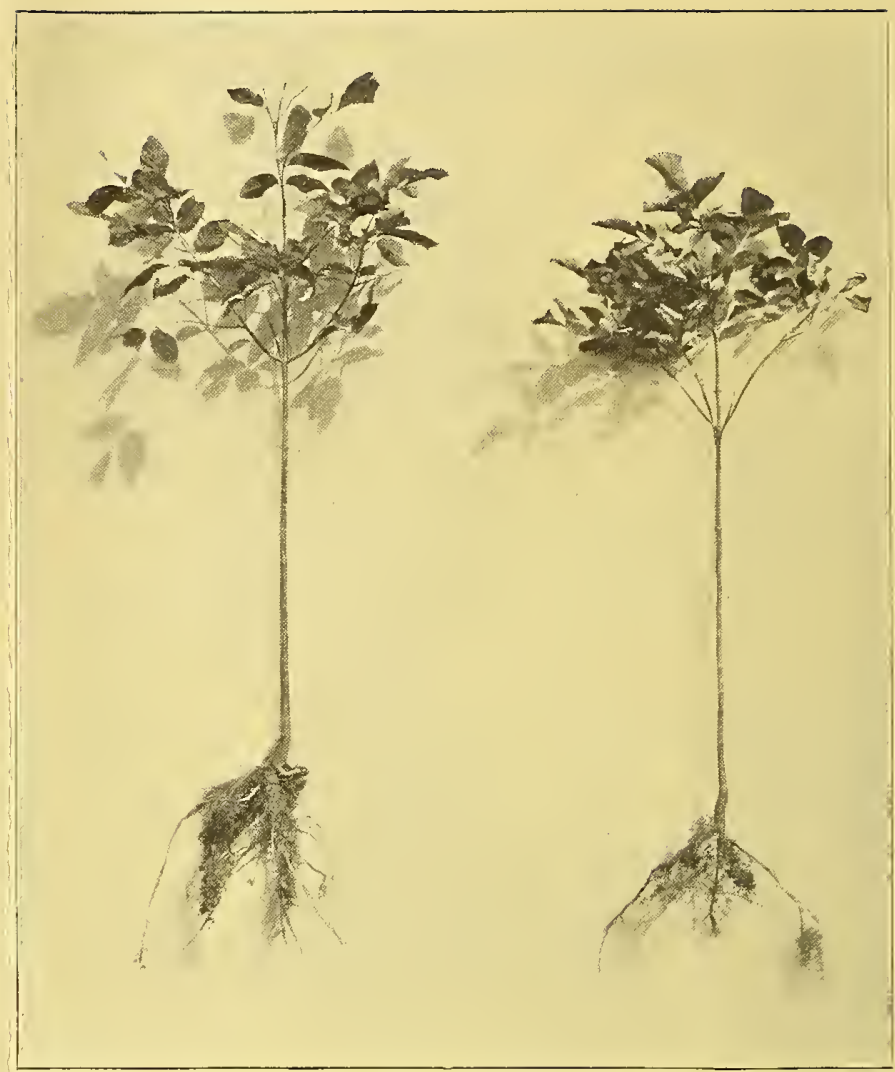

WHITE ASH grown from Massachusetts Seed. Four-year transplant on left, three-year seedling on right.

The true American White Ash (Fraxinus Americana) is onc of the most important and valuable trees of the country. It thrives on lands too wct for inost spceies, and also does remarkably well on drier lands. It should not, however, be planted in the shade. For timber, shade and street planting it is highly valued. It is of remarkably rapid growth, and is practically iminune from insects.

Forest owners are actively planting this species because of its many desirable qualities and the scarcity and high price

\begin{tabular}{|c|c|c|c|}
\hline \multirow{3}{*}{\multicolumn{2}{|c|}{$\begin{array}{l}\text { HEIGHT } \\
\text { FRAXINUS LANGEOLATA, Borkh. }\end{array}$}} & \multicolumn{2}{|c|}{ Prices in Lo } \\
\hline & & 10 & 100 \\
\hline & & & \\
\hline Twice Transplanted .... & 6 to $8 \mathrm{ft}$. & $\$ 3.00$ & \\
\hline Twice Transplanted & 4 to $6 \mathrm{ft}$. & 2.00 & $\$ 10.00$ \\
\hline Transplanted....... & 3 to $4 \mathrm{f}$ & 1.25 & 6.00 \\
\hline Transplanted ....... & 2 to $3 \mathrm{ft}$. & 1.00 & 4.50 \\
\hline
\end{tabular}
of its wood. Our plants arc straight, heavy stemmed, vigorous, elcan and uniformly well rooted.

GLEDITSIA TRIACANTHOS, Linn.

Twice Transplanted .... t to $5 \mathrm{ft}$.

Twice Transplanted ... 3 to $t \mathrm{ft}$.

Twice Transplanted ....2 to $3 \mathrm{ft}$.

Transplanted........ 1 to $2 \mathrm{ft}$.

Seedling .......... 3 to $4 \mathrm{ft}$.

Seedling ........... 2 to $3 \mathrm{ft}$.

Seedling .......... 1 to $2 \mathrm{ft}$.

Seedling ........... 8 to 12 in.
Honey Locust

$\$ 3.00$

2.25

2.00

$1.00 \$ 4.00$

4.00

3.00

1.75

1.25

$\$ 6.50$ 
Prices in Lots of

HICORIA GLABRA, Britt.

Seedling

Seedling

8 to 12 in.

4 to 8 in.

Pignut (Hickory)

$\$ 1.00 \$ 5.00$

$3.00 \$ 25.00$

HICORIA OVATA, Britt.

Shellbark-Shagbark Hickory

Transplanted 8 to 12 in.

Transplanted 4 to 8 in.

$\$ 2.00 \$ 10.00$

$1.25 \quad 6.00$

JUGLANS CINEREA, Linn.

Transplanted......... $1 \frac{1}{2}$ to $2 \mathrm{ft}$.

Seedling $\ldots \ldots \ldots \ldots 2$ to $3 \mathrm{ft}$.

Seedling $\ldots \ldots \ldots \ldots \ldots 1$ to $2 \mathrm{ft}$.

\section{JUGLANS NIGRA, Linn.}

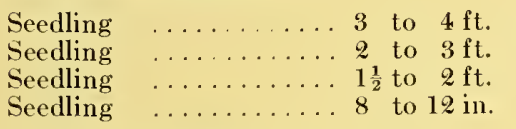

\section{OSTRYA VIRGINIANA, K. Koch.}

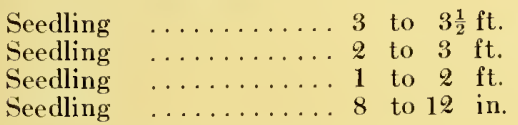

\section{POPULUS BALSAMIFERA, Linn.} $\begin{array}{rrrrrr}\text { Rooted Plants } \ldots \ldots \ldots \ldots & \text { to } 5 \mathrm{ft} . & \$ 1.60 & \$ 8.00 \\ \text { Rooted Plants } & \ldots \ldots \ldots & \text { 2 to } & 3 \mathrm{ft} . & 1.00 & 5.00\end{array}$ Cuttings .......... About $1 \mathrm{ft}$. long.

POPULUS DELTOIDES, Marsh.

Rooted Plants .......4 4 to $6 \mathrm{ft}$. $\$ 1.75 \quad \$ 9.00$ Rooted Plants ....... 3 to $4 \mathrm{ft}$. $1.25 \quad 6.00$ Rooted Plants ........ 1 to $2 \mathrm{ft}$. Cuttings .......... About $1 \mathrm{ft}$. long.

$\$ 2.50 \$ 12.00$

$\begin{array}{lll}1.80 & 9.00 & \$ 75.00\end{array}$

$\begin{array}{lll}1.35 & 6.50 & 55.00\end{array}$ $3.50 \quad 25.00$

Balm of Gilead

$\$ 6.00$ POPULUS DILATATA, Linn.

Rooted Plants ....... 7 to $9 \mathrm{ft}$. Rooted Plants ........ 5 to $7 \mathrm{ft}$.

Rooted Plants ........ 3 to $5 \mathrm{ft}$.

Cuttings

About $1 \mathrm{ft}$. long.

Lombardy Poplar

$\$ 2.75 \$ 13.50$

$2.00 \quad 10.00$

$1.50 \quad 7.50$

POPULUS GIGANTEA.

$\$ 6.00$

Rooted Plants ........ 10 to $12 \mathrm{ft}$.

Rooted Plants ........ 8 to $10 \mathrm{ft}$.

Cuttings

About $1 \mathrm{ft}$. long.

Norway Poplar

QUERCUS BICOLOR, Willd.

Transplanted......... 2 to $3 \mathrm{ft}$.

Transplanted......... 1 to $2 \mathrm{ft}$.

QUERCUS IMBRICARIA, Michx.

Twice Transplanted ... 3 to $5 \mathrm{ft}$. $\quad \$ 3.50$

Twice Transplanted .... 2 to $3 \mathrm{ft}$. 2.25

QUERCUS MACROCARPA, Michx.

Transplanted........4 to $5 \mathrm{ft}$. Transplanted......... 3 to $4 \mathrm{ft}$.

Transplanted......... \& to $3 \mathrm{ft}$.

Transplanted......... 1 to $2 \mathrm{ft}$.

\section{HEIGHT}

Prices in Lots of

QUERGUS PALUSTRIS, Muench.

$\left[\begin{array}{lll}10 & 100 & 1,000\end{array}\right.$

Twice Transplanted ... 7 to $9 \mathrm{ft}$. $\$ 10.00 \$ 50.00$

Twice Transplanted .... 55 to $7 \mathrm{ft}$. $8.00 \quad 40.00$

Twice Transplanted ... 4 to $5 \mathrm{ft} . \quad 6.00 \quad 30.00$

Twice Transplanted ... 3 to $4 \mathrm{ft} . \quad 5.00 \quad 25.00$

Transplanted ........ 6 to $8 \mathrm{ft} . \quad 6.00 \quad 30.00$

Transplanted ........ 4 to $6 \mathrm{ft} . \quad 4.00 \quad 20.00$

Transplanted........ 3 to $4 \mathrm{ft}$. $2.50 \quad 12.00$

Transplanted........2 to $3 \mathrm{ft} . \quad 1.75 \quad 8.50$

(See illustration and description of our Pin Oaks on Page 20.)

QUERGUS RUBRA, Linn.

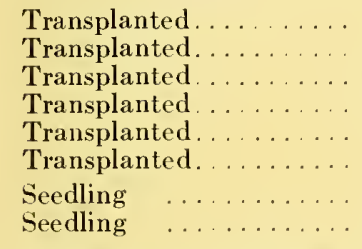

7 to $9 \mathrm{ft}$
5 to $7 \mathrm{ft}$
4 to $5 \mathrm{ft}$.
3 to $4 \mathrm{ft}$
2 to $3 \mathrm{ft}$.
1 to $2 \mathrm{ft}$
1 to $1 \frac{1}{2} \mathrm{ft}$
8 to $12 \mathrm{in}$.

$\$ 4.50 \$ 22.00$

$3.00 \quad 15.00$

$2.00 \quad 10.00$

$1.50 \quad 8.00$

$1.00 \quad 5.50$

4.00

$1.50-10.00$

Red Oak is becoming the most popular oak for ornamentol as well as com mercial planting. Its rapid growth and thoroughly satisfactory development, as well as its beauty and its large volume of sound, valuable wood make it so. It has a wide natural range, growing successfully on the dry, sandy land of Cod and Long Island, while on richer, moister lands it reaches a height of seventy to ninety feet and a diameter of three or four feet.

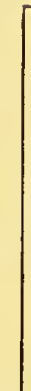


TILIA PARVIFOLIA, Ehrh.

Twice Transplanted

Twice Transplanted

Twice Transplanted

Twice Transplanted

Transplanted.

Transplanted.

Transplanted.

Seedling

Seedling

Seedling

\section{HEIGHT}

7 to $9 \mathrm{ft}$

5 to $7 \mathrm{ft}$.

3 to $5 \mathrm{ft}$.

2 to $3 \mathrm{ft}$.

3 to $4 \mathrm{ft}$.

2 to $3 \mathrm{ft}$.

1 to $2 \mathrm{ft}$.

3 to $5 \mathrm{ft}$.

2 to $3 \mathrm{ft}$.

1 to $2 \mathrm{ft}$.
Prices in Lots of $10 \quad 100 \quad 1,000$

European Linden

$\$ 5.00 \$ 25.00 \$ 220.00$

$\begin{array}{lll}3.60 & 18.00 & 165.00\end{array}$

$3.00 \quad 15.00 \quad 140.00$

$2.00 \quad 10.00 \quad 90.00$

$\begin{array}{ll}1.80 & 9.00\end{array}$

$\begin{array}{lll}1.25 & 6.00 & 50.00\end{array}$

$\begin{array}{lll}1.00 & 4.00 \quad 30.00\end{array}$

$\begin{array}{lll}1.00 & 5.00 & 40.00\end{array}$

$3.50 \quad 25.00$

$2.75 \quad 18.00$
Our European Lindens, small-leaved variety, make beautiful ornamental trees and are very desirable for lawn, park and avenue planting.

ULMUS AMERICANA, Linn.

Prices in Lots of

HEIGH'T $10 \quad 100 \quad 1,000$

Twice Transplanted ... . 5 to $7 \mathrm{ft}$. $\$ 4.00 \$ 20.00$

Twice Transplanted ... \& to $5 \mathrm{ft}$. $\quad 3.00 \quad 15.00$

Twice Transplanted … 3 to $4 \mathrm{ft} . \quad 2.50 \quad 12.00 \$ 100.00$

Twice Transplanted ... 2 to $3 \mathrm{ft}$. $\quad 2.00 \quad 10.00$

Transplanted

Transplanted

2 to 3 it.

$1.00 \quad 5.00 \quad 40.00$

The American Elm is always in demand, always beautiful, and always valuable.

\section{A FEW OF THE MANY KINDS OF SHRUBS WE HAVE FOR SALE}

\section{Prices in Lots of}

AMPELOPSIS QUINQUEFOLIA, Michx. Virginia Creeper

Seedling

+ years old

$\$ 2.00 \$ 15.00 \$ 125.00$

Seedling

3 years old

$\begin{array}{lll}1.50 & 10.00 & 90.00\end{array}$

\section{BERBERIS THUNBERGII.}

Secdling

Seedling

\section{BERBERIS VULGARIS.}

Transplanted

Transplanted
8 to 12 in.

4 to 8 in.

Japanese Barberry

$\$ 4.50 \$ 35.00$

$3.00 \quad 20.00$

Common Barberry

2 to $3 \mathrm{ft} . \$ 3.00$

$1 \frac{1}{2}$ to $2 \mathrm{ft} . \quad 2.00$
Seedling

Secdling

LIGUSTRUM REGELIANUM.

Transplanted

Transplanted

2 to $3 \mathrm{ft}$.

1 to $2 \mathrm{ft}$

VITIS SOLARIS.

Transplanted

Transplanted
2 to $3 \mathrm{ft}$.

$1 \frac{1}{2}$ to $2 \mathrm{ft}$
Prices in Lots of

HEIGH'T $\quad 10 \quad 100 \quad 1,000$

to $3 \mathrm{ft} . \quad \$ 2.50 \$ 12.00$

$3.00 \$ 20.00$

We only list in this booklet those kinds of trees and shrubs we raise in large quantities. If you do not find what you are especially interested in, please send us a list of your requirements and we will make you quotations to cover your needs.

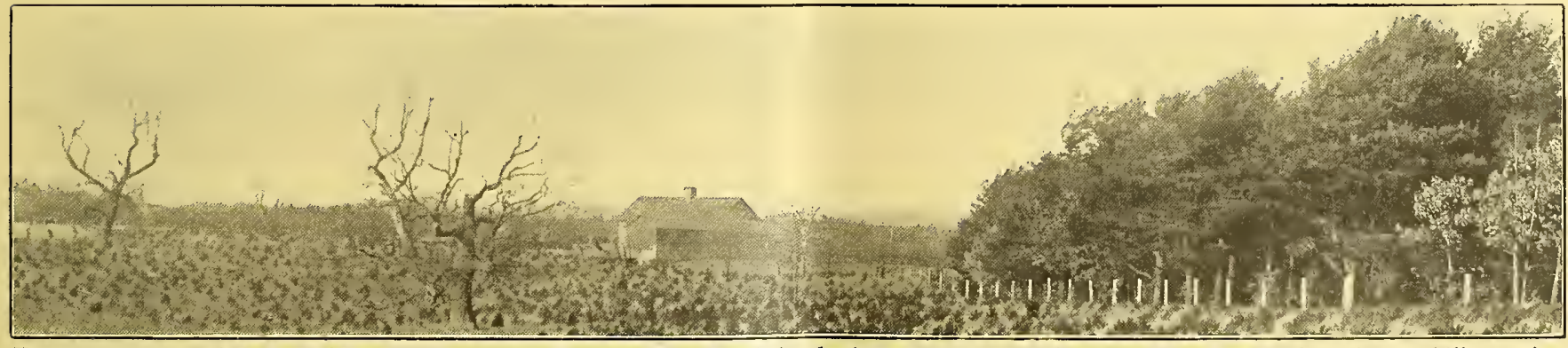

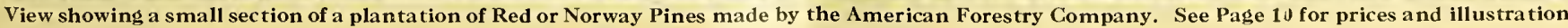
of our Red Pines. Individual Red Pine is shown on Page 15. 


\section{MASSACHUSETTS}

Plantations - not less than 2000 trees to the aere, upon land whieh does not exceed $\$ 10.00$ per acre - exempt from taxation for ten years after trees have grown two feet.

\section{NEW HAMPSHIRE}

Land planted - at least 1200 to the acre, tax rebated. First ten years, 90 per cent. fecond ten years, 80 per eent. Third ten years, 50 per cent.

\section{CONNEGTICUT}

Taxed annually on the land alone, rate not to exceed 10 mills, plus a riekl tax of 10 per cent on value when cut.

\section{VERMON'T}

Tax exempt for ten years.

\section{MAINE}

Not less than 640 to the acre after three years may be tax exempt for twenty ycars.

\section{RHODE ISLAND}

Land not worth more than $\$ 25.00$ an aere, planted not less than 500 to the acre, tax exempt for fifteen years.

\section{NEW YORK}

Not less than 800 to the acre, tax exempt for thirty-five years. A 50 per cent reduction for thirty-five years for underplanting existing forest and brush lands with not less than 300 trees. Waste, denuded, or wild forest lands 5 acres or more, assessed at not over $\$ 5.00$ per acre which is forested under agreement with the Conservation Commission, taxed for thirty-five years on land alone at a valuation not to exeeed that at the beginning of the period.

\section{PENNSYL VANIA}

Lands used exclusively for growing trees and classified as auxiliary forest reserves rated for taxation at not in excess of $\$ 1.00$ per acre. 'Timber subject to 10 per cent yield tax when harvested.

Several Other States Have Similar Exemption Laws

\section{SUGGESTIONS FOR TREE PLANTING}

\section{ORDER EARLY, PLANT PROMPTLY AND SUCGEED}

\section{THE PROPER THME TO PLANT}

In spring - as soon as the snow bas gone and the frost is out of the ground ardwoods and larches as early as possible, before the buds begin to start ergreens immediately after these.

In fall - the latter part of August and all September for most evergreens october and November are desirable month for transplanting deciduous trees

\section{USUAL DISTANCES BETWEEN PLANTS FOR FOREST PURPOSES}

White Pine $-4 \times 4 \mathrm{ft}, 5 \times 5 \mathrm{ft}, 6 \times 6 \mathrm{ft}$.

Douglas Spruce $-4 \times 4 \mathrm{ft} ., 5 \times 5 \mathrm{ft}$

Balsam Fir - 4 x 4 ft., 5 x $5 \mathrm{ft}$.

European Larch $-5 \times 5 \mathrm{ft} ., 4 \times 6 \mathrm{ft}$.

Red Oak $-4 \times 4 \mathrm{ft}$., $4 \times 6 \mathrm{ft}$.

White Ash $-5 \times 5 \mathrm{ft}, 6 \times 8 \mathrm{ft}$

Sugar Maple - $5 \times 5 \mathrm{ft} ., 4 \times 6 \mathrm{ft} ., 7 \times 7 \mathrm{ft}$

Birch $-4 \mathrm{x}+\mathrm{ft}, .5 \times 5 \mathrm{ft}$

Black Locust - $4 \times 4 \mathrm{ft}, 3 \times 6 \mathrm{ft}, 5 \times 5 \mathrm{ft}$.

NUMBER OF PLANTS ON AN ACRE A'T VARIOUS DISTANGES

\begin{tabular}{|c|c|c|c|}
\hline $\begin{array}{l}\text { Feet } \\
3 \times 3 \\
4 \times 4 \\
5 \times 5 \\
5 \times 6 \\
5 \times 8 \\
6 \times 6 \\
6 \times 7\end{array}$ & $\begin{array}{r}\text { Plants } \\
4,840 \\
\quad 2,723 \\
\quad 1,743 \\
\quad 1,452 \\
1,059 \\
1,210 \\
1,038\end{array}$ & $\begin{array}{l}\text { Fcet } \\
7 \times 7 \\
8 \times 8 \\
9 \times 9 \\
10 \times 10 \\
12 \times 12 \\
16 \times 16 \\
20 \times 20\end{array}$ & $\begin{array}{r}\text { Plants } \\
. \quad 889 \\
681 \\
\ldots \quad 538 \\
.436 \\
. \quad 302 \\
\ldots \quad 171 \\
. \quad 109\end{array}$ \\
\hline
\end{tabular}

WHAT PLANTS TO USE

While fine seedlings are perfectly suitable for eommercial forest planting under favorable conditions, it should be borne in mind that transplanted stock always has more endurance. (Seedlings are plants raised from seed and remaining in the beds where they are sown. Transplants are plants whieh have been taken from the seed bed and replanted in the nursery one or more times.) Transplanting produces general stoekiness and an abundance of fibrous roots. It is false economy to set seedlings in plaees or for purposes where transplanted stoek should be used. Transplants are able to withstand far more adverse condltlons of soil and weather, and to make a faster growth than verse condlthons of soil and weather, and to make a faster growth than
seedllngs. We would urgently recommend transplanted stock for all rough, stony, brushy, or especially dry and exposed land, and in general for the quiekest and most noticeable results. Amateur planter8, especlally, are advlsed to use transplanted trees.

\section{CARE OF PLANTS ON ARRIVAL}

Upon reccipt of the plants, take them from the boxes, open the bundles and immerse the roots in water. Then spread the plants in thin layers, and heel them into the ground at an angle of 30 to 40 degrees, leaning the tops of the plants toward the south, and cover the roots with about 6 inehes of moist soil. The best place for sueh heeling-in is in a cool, shady spot, such as the north side of buildings. 'The plants must be proteeted from the drying winds, and the roots never exposed to direet sun or wind. If plants arrive frozen, or in freezing weather, put the boxes in a eool but frost-proof eellar frozen, or in freezing weather, put the boxes in a eool but frost-proof eeliar
or shed, and leave them until thorouglily thawed. If the plants should arrive somewhat heated, it is best to plant them immediately, or, if that be impossible, to heel them in, not too closely, in a cool cellar, taking pains to give them extra air. It is important not to wet the roots too mueh when heeled-in in a damp eellar, as they will deeay if too wet.

\section{HOW TO PLANT LiTTLE FOREST TREES}

Before planting, the roots should be thoroughly soused in a "puddle" Before planting, the roots should be thoroughly soused in a "pudde" ordinary paint. The plants should be carried to the field either in a bucket containing puddle or water, or in a basket with burlap or some sueh covering to protect the roots previously puddled. Any very long, superfluous root should be eut off with a sharp knife or eleaver. In the case of small hardwood seedlings, with a strong tap-root, eut the tap-root baek to a length of 8 or 10 inehes, making a downward slanting cut. There must be no exposure of the roots to the sun or drying winds, before setting, as plants are almost surely killed in this way; this is especially true of evergreens. Remember, plants are alive, and they will die if proper conditions are not given them. plants setting the trees, two men work together, one earrying the plants and setting them, the other making the holes. 'The best all-around digging tool setting them, the other making the holes. The best all-around digging tool
is the double-edged eutting hoe, or mattoek. While one man makes the hole, is the double-edged eutting hoe, or mattoek. While one man makes the hole,
the second man (or boy) places the plant in the hole with the roots straight down and spreading in a natural position. 'The best well-broken or "fined" soil must then be paeked so solidly about the roots as to be air-tight. The plant should generally be set about $1 / 2$ to 1 ineh deeper than it was originally in the nursery, to allow for the settling of the ground; after settling, it should be just as deep as it was in the nursery. Great eare must be taken not to set small plants too deep, especially in heavy soils. The roots can hardly be packed too firmly. Setting plants early in the spring, when the ground is still moist and the air cool, insures against such a eostly and impracticable proceeding as watering after planting.

\section{CARE AFTER PLANTING}

A well-set plantation requires very little after-eare. Cattle must be kept out at least for some years, if not entirely, and of course the plantation must be protected from fire. If the planting be sufficiently elose, no pruning will be protected from fire. If the planting be sufficiently elose, no pruning wil
be required. But in ease some plants dying leave space enough for adjoining trees to grow "limby," the latter should be pruned after about ten years, dead and superfluous limbs being cut close to the trunk. This is best done in the fall, when the sap, running sluggishly, will cover wounds without mueh bleeding. 


\section{BEAUTIFY YOUR HOME AND GROUNDS BY PLANTING LITTLE TREES}

And where is there a landowner who does not desire trees to beautify his home and grounds, whether they are large or small? Property without trecs and shrubs has a barren and desolate appearance. Even a few trces add greatly to the landscape beauty of an estate. Many landowners realize that shade and ornamental trees on an estate are not only a source of pleasure, but also that they greatly increase property values. We cater not only to the landowners who use large quantities of trees, but also to those who can only use them in limited quantities.

\section{LITTLE TREE GARDENS}

Why not plant rows or beds of little trees in your garden, to be set in permanent places as they grow large enough? You can use them for borders and hedges, along paths, and around the vegetable garden; and as they grow, keep such hedges as you wish, transplanting the other trees where they are needed on your property. They will afford you pleasure and interest from the first, and greatly lessen the expense of the ultimate plantation.

The little trees require very slight care, practically nothing but weeding, and their varied characteristics and thcir frequent changes from season to season are a constant delight and surprise. They grow rapidly, some kinds doubling their growth annually for several seasons, while others increase from one to three feet each year.

Such a little tree garden, or a private nursery, - and of these we have furnished hundreds, - adds much to the value of an estate. Transplanting can be done at any time, without delay, and at any stage when plants are ready to produce the effect desired. Set them on some waste land or unsightly spot, in groves or singly, along an avenue, or to use as windbreaks, screens, or hedges.

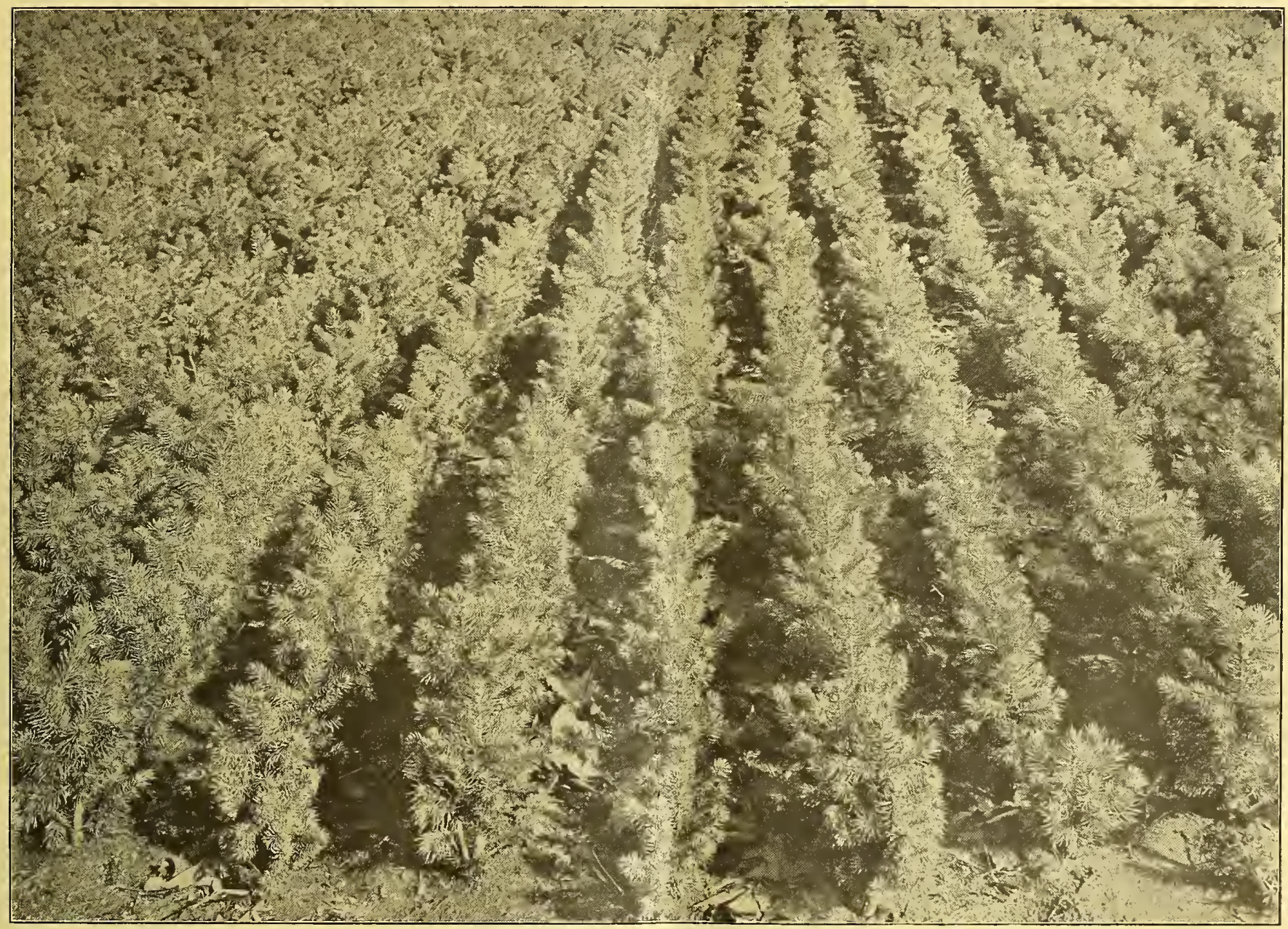

ROWS OF FOUR-YEAR OLD TRANSPLANTED COLORADO BLUE SPRUCES AT Itittle Eree Ifaruts af Autrira

(For illustration of individual tree, prices and description of Blue Spruce see Page 9.) Blue Spruce is one of the many desirable conifers for planting in little tree gardens, later on to be transplanted as ornamentals on an estate.

\section{AMERICAN FORESTRY COMPANY,}

Fifteen Beacon Street,

BOSTON,

MASS. 


\section{ARE YOU A} TREE

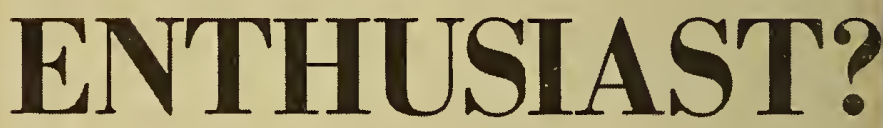

If not-become one START RIGHT!

Procure the BEST TREES Possible We Have Them and at the Lowest Market Prices

\section{WE NOW HAVE 2000}

ANNUAL CUSTOMERS using our Trees who are becoming more enthusiastic tree planters each year

\section{WHY?}

BECAUSE OUR TREES

$$
\text { GROW }
$$

American Forestry Compan 15 Beacon Street - Boston, Massachusetı 